\title{
The four ages \\ of early prestressed concrete structures
}

\section{Marc Sanabra-Loewe and Joaquin Capellà-Llovera}

This paper discusses the development of prestressed concrete technology, bringing together previously compiled historical studies and new information from European and United States patents.

The authors divide the early history of prestressed concrete into four ages: intuition, optimistic engineering, minimization of losses, and effective prestressing.

The "four ages" perspective can also be applied to other types of prestressing technology.
$\mathrm{P}$ restressing is simply introducing loads to a structure to enable it to withstand larger service loads. However, as Freyssinet summarized in the foreword of Guyon's reference book, "This idea is of an extreme simplicity in its foundation, even if it is not in the execution." 1 That is why even though prestressing has been used in structures and everyday objects since prehistoric times (for example, bows and tents), it has only been completely understood and implemented in the past century. The development from first intuition through full material control may be divided into four main phases, or ages: intuition, optimistic engineering, struggling to minimize losses, and effective prestressing. This division can be used for the study of the historical evolution of prestressed structures composed of any material.

In the first age, the benefits of prestressing are intuited by the designer. In the second age, thanks to engineers, the main principle is rationally understood and implemented: preloads are designed to act in opposition to service loads. The third age is characterized by the recognition that losses exist but are not easily quantifiable or effectively controlled. Finally, the fourth age is that of complete understanding of the long-term behavior of materials and of engineering solutions able to overcome the effects of losses.

Concrete was not the first material used in prestressed structures (first age) or the first used in engineered prestressed structures (second age), but it has been the first to 


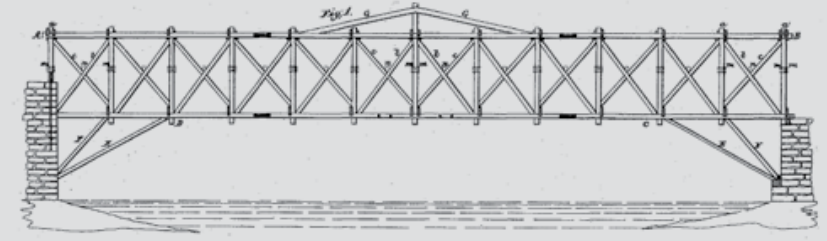

Figure 1. Prestressed wooden bridge as designed by Stephen H. Long. Source: U.S. Patent X5862 (1830).

reach the fourth age. This evolution has occurred because concrete is the first material in which losses have been completely understood (at least for most types of structures). ${ }^{2}$

The first engineered prestressed structures were composed of wood, wrought iron or steel, and cast iron. Prestressed concrete is to a certain degree the heir of those early prestressed structures, as demonstrated by the career of Peter H. Jackson, who is most often cited as the first person to propose prestressing concrete. Therefore, it is fair to preface the history of prestressed concrete with the first prestressed timber, wrought iron, and cast iron structures.

This paper concentrates on the history of prestressed concrete using three main strategies to add resources. First, the two main families of histories of prestressed concrete are merged, resolving the dichotomy ${ }^{3}$ between the early English $^{4,5}$ and German texts ${ }^{6,7}$ and those based primarily on the life of Freyssinet. ${ }^{3}$ Second, recent studies on the early expansion of prestressed concrete through Europe are compiled. Finally, new data are presented from early patents on prestressed concrete.

\section{The first age: Prestressing by intuition}

Any structure or object where tightening is used can be considered to be prestressed. That statement gives an idea of how ancient this principle is. When the first tight knot was made with a sewing thread or the first bow was made, prestress appeared in its essence: the material thus treated became tighter and stiffer and thus stronger. The first structures using those principles may have been temporary tents or awnings. At that time, long-term losses were far from being seen as rheological phenomena related to environmental and material conditions. However, it must have been quickly discovered that tightened structures or objects had to be retightened from time to time. Thousands of years after those early structures were constructed, another powerful instance of a prestressed structure was achieved: the construction of the first sailboat (likely Egyptian) in which the mast was prestressed and stabilized by pretensioned stays. At the end of this first age of prestress there were masonry arches tied with wooden posts (Kairouan [or Uqba] Mosque, ninth century AD) or iron rods (Lombard medieval churches, such as the Parma Cathedral, twelfth century AD). This technique of tying arches, made classical by the Italian Renaissance, does not typically use prestress, or only a slight one. However, it inspired pioneering designers of prestressed structures; it was quoted numerous times by engineers from Whipple to Freyssinet.

\section{The second age of prestressed structures: Engineering optimistically}

\section{First prestressed timber structures: 1829-1830}

In 1995, Griggs and DeLuzio ${ }^{8}$ showed that the earliest engineered prestressed structures were likely made of timber by the military engineer Stephen Harriman Long (1784-1864). He became the first structural engineer of the United States when he participated in the design and construction of the Baltimore and Ohio Railroad. Shortly after becoming interested in bridge construction (1827), Long built an ingenious prestressed truss timber bridge ${ }^{9}$ in Baltimore in 1829, named Jackson Bridge after the seventh U.S. president, Andrew Jackson. He patented the system the next year (Fig. 1).$^{10}$ Although the original patent was lost in the patent office fire of 1836, the bridge design was also described by Long in several other documents.

It spanned $109 \mathrm{ft}(15 \mathrm{~m})$ and was made of two cross-braced trusses. The trusses were built in a slightly arched shape and, before completion, they were preloaded and then braced so that the preload was maintained and enhanced the structural behavior. The bridge was constructed in the following manner:

- The trusses were built (slightly arched) with their upper and lower chords connected by vertical posts and nailed so that they were only able to withstand compression and tension.

- The compression braces (those with the upper part pointing to midspan) were wedged against the chords and posts.

- The bridge was loaded uniformly so that the braces were under heavy compression. In that condition, the counter braces were wedged into place and the preload released (Fig. 2). Consequently, under dead loads the counter braces were considerably precompressed and the braces became considerably decompressed. Thus, both sorts of braces were precompressed. ${ }^{10}$

When the structure was preloaded, it was less stiff than after complete bracing and release of the preload. Thus, when that preload was eliminated, the structure did not recover its original shape because it lost some of its original camber. If Long's wooden bridge is compared with the nearly identical concrete system patented by the eminent civil engineer Ulrich Fintserwalder ${ }^{11}$ nearly 100 years later, 
one can see that Finsterwalder did not mention that the truss should be built in an arched manner, which makes his proposal less clever than Long's, indicting the sophistication of Long's design. The refinement in what is considered his first bridge may indicate that this structure was not really his first construction of that type. Although Long's ingenuity is unquestionable, he did not know that the initial precompression would decrease significantly with time due to creep, losing efficiency. In any case, the bridge was dismantled in 1860. A few years after the construction of the Jackson Bridge, Long made other proposals for prestressed timber structures and suggested the possibility of prestressing iron. ${ }^{9} \mathrm{He}$ was not the only designer to do so. Indeed, a number of other technicians and craftsmen, including Nathaniel Rider, William Howe, and Thomas and Caleb Pratt, ${ }^{8,9}$ took inspiration from his work and either patented and built their own variations of prestressed timber structures or combined prestressed iron and timber structures. Their prestressed wooden structures, particularly Howe's, were widely used during the mid-nineteenth century. ${ }^{9}$

\section{Prestressed cast iron structures in Europe: 1836-1848}

The first European prestressed structures designed by engineers appear to have been cast iron trussed compound girders for bridges designed and built around 1836 or 1839 by the English engineers Robert Stephenson (1803-1859) and George Parker Bidder (1806-1878). Although the Irish engineer Charles Blacker Vignoles (1793-1875) took credit for the invention, several authors consider Stephenson to be the real inventor. ${ }^{12,13}$ Although those early bridges were not designed correctly ${ }^{13}$ and should be classified as first-age structures, their development was closely related to the first European second-age prestressed structures explained in the following paragraphs. Those compound trusses were composed of three cast-iron truss segments joined by bolts and prestressed externally by flat wrought-iron ties working as polygonal tendons (Fig. 3).

As discussed by Sutherland, ${ }^{13}$ the layout of these tendons was not designed correctly and would have been more appropriate for an indeterminate truss because the forces induced by prestressing caused considerable positive moments near the bearings and a small negative moment in the center of the bay, where it should have been greater (Fig. 4). These types of bridges were built by the dozen in England until 1847, when the famous collapse of one of these structures occurred in Chester over the Dee River, killing five people. Shortly after the disaster, a royal commission was established to evaluate the reliability of different types of steel bridges and determine the causes of the Dee Bridge disaster. Both the disaster and the commission undermined confidence in cast-iron bridges and, to a certain extent, the prestige of Stephenson. He was obliged to strengthen a large number of trussed compound girders and decided to stop using that system in future bridges.
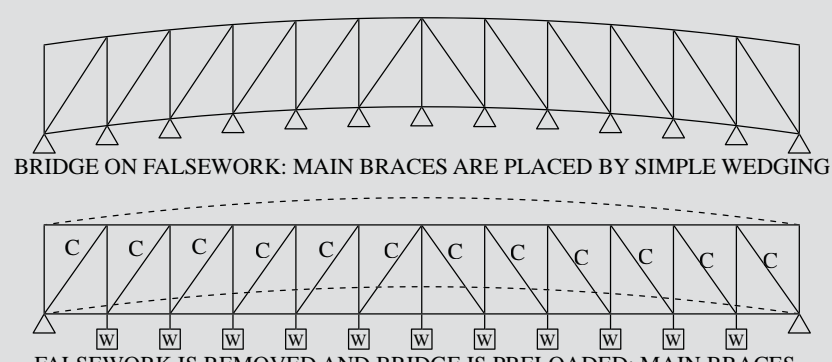

FALSEWORK IS REMOVED AND BRIDGE IS PRELOADED: MAIN BRACES ARE PRECOMPRESSED

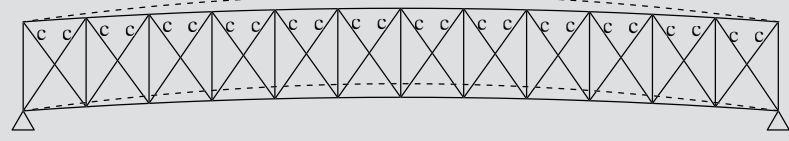

BRIDGE IS UNLOADED: COUNTERBRACES ARE COMPRESSED AND MAIN BRACES PARTIALLY DECOMPRESSED

Figure 2. Schematic loading process of Long's Bridge.

As a consequence, William Fairbairn's (1789-1874) wroughtiron riveted tubular bridges reigned in popularity, and cast iron and the idea of prestressed structures were set aside. A notable exception to these dramatic changes was a bridge designed and built by Charles Heard Wild (1819-1857), a brilliant young engineer working for Stephenson. Some years before the Dee Bridge disaster, Stephenson was given the contract to design and build several bridges in Italy on the Leopold Railway from Florence to Leghorn (Livorno). When the accident occurred in Chester, all but one of the bridges in Italy had been built (or were nearly complete) with Stephenson's typical trussed compound girders, so he decided to reinforce them, as he did with many bridges in England. The bridge over the Arno River was furthest from completion, so it was completely redesigned (apparently by Wild), becoming an efficient prestressed cast-iron bridge. The new design retained the idea of bolted cast-iron segments, but this time, instead of straight-line I-shaped segments (simple beams), the segments were those of a truss in which the lower chord was flat and the higher chord arched. Thanks to this design feature, the compression chord was efficiently compressed and a parabolic optimization was obtained against the parabolic moment diagram. The prestressed tendons were straight and parallel to the lower chords, that is, exactly where they were needed, causing a prestressed moment diagram of opposite sign to the moment diagram of the external loads (Fig. 5).

Another interesting feature of that design is that Wild mentioned the possibility of modifying it in such a way that the prestress was either total or partial. He described, then, the essential principles of partial prestress. ${ }^{13,14}$ Unfortunately it appears that the bridge was strongly reinforced with stone masonry at the end of the nineteenth century and was dismantled in the middle of the twentieth century.

\section{First prestressed cast-iron structures in the United States: 1840-1845}

The idea of prestressing cast iron was not unique to Great 


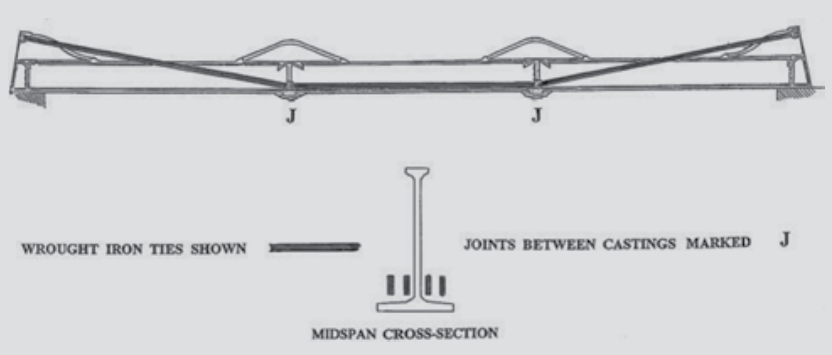

Figure 3. Cast iron trussed compound girder designed by Robert Stephenson. Source: Reproduced by permission from Maney Publishing (2009).
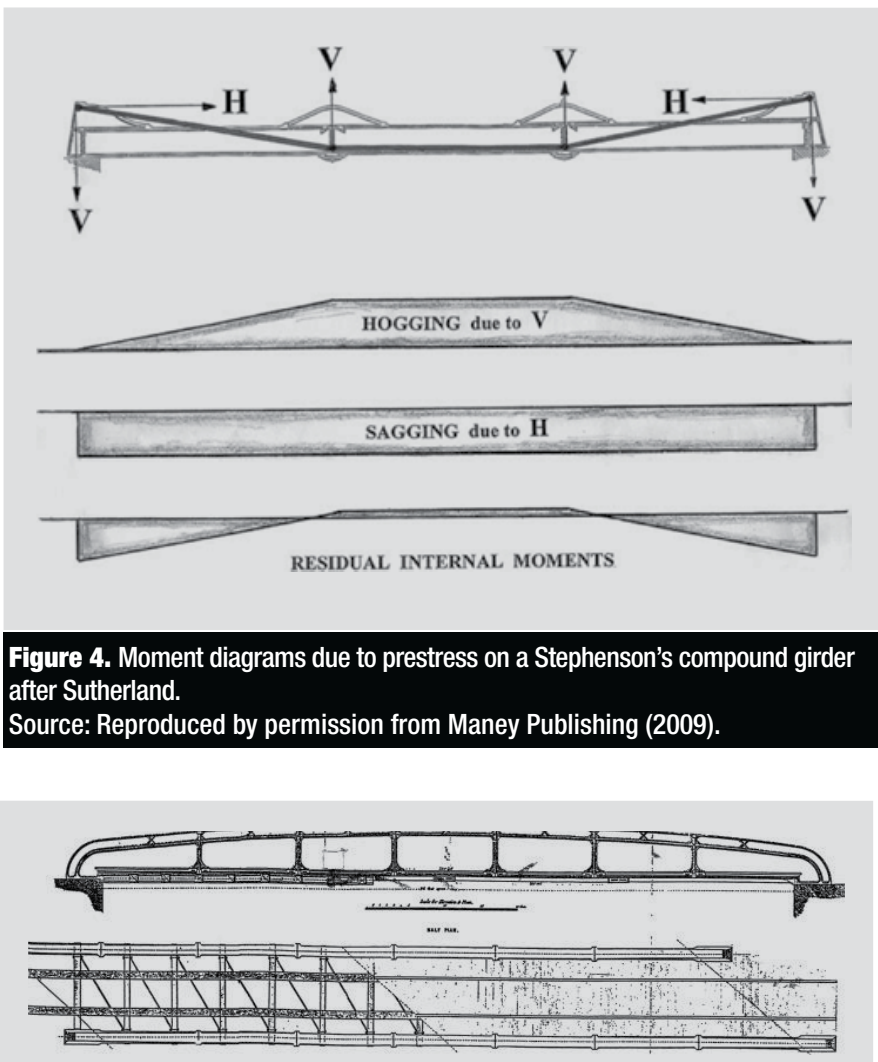

Figure 5. Elevation of the Arno Bridge as designed by Robert Stephenson and Charles Heard Wild. Source: Reproduced by permission from Maney Publishing (2009).

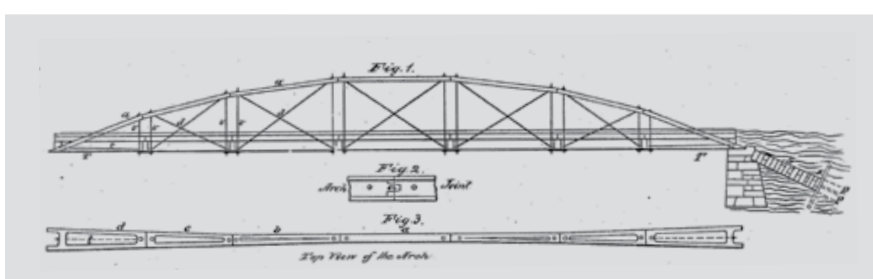

Figure 6. Prestressed cast iron bridge as designed by Squire Whipple Source: U.S. Patent 2064 (1841).

Britain. Less than five years after the first prestressed castiron bridges were built in Europe, Squire Whipple (18041888) developed his own original system in the United States. His proposal, first designed in 1840 and patented soon $\operatorname{after}^{15}$ (Fig. 6), was built in $1845^{16}$ and closely resembled that of Wild's (though Whipple's design predated Wild's by at least seven years).

Although the two designs have similar features, they also have important differences, and nothing indicates that either influenced the other. Whipple's bridges (some of them still standing) are supported by arched trusses with or without vertical posts and crossed braces or ties. The upper chord is an arch made of cast-iron segments bolted together, and the lower chord a straight wrought-iron tendon. One of the most interesting features of this bridge is that the tendon is tightened by precompressing the vertical posts (or braces if there are no posts) so that they push away the tendon to give it a polygonal layout. ${ }^{8}$ In some ways it works similarly to Long's Jackson Bridge, as in both cases the principle of prestressing consists of applying pretension in both chords and precompression to the posts (or braces). The possibility should not be dismissed that Long influenced Whipple, as they both worked on the Baltimore and Ohio Railroad during the 1830s. Whipple's bridge system made a considerable fortune during the 1850s and 1860s and was used in several small or medium-sized overpasses and bridges across the Erie Canal, among others. ${ }^{16}$ Nonetheless, it was never used in major bridges. Over his career, Whipple developed other types of iron bridges using prestress techniques. Other engineers, including Nathaniel Rider, Stephen Moulton, and T. and C. Pratt also did so after Whipple's or Long's works. ${ }^{9}$

\section{The first and second ages of prestressed concrete structures}

There is a qualitative difference between the intuitive technical solutions of the first age and the engineered solutions of the second age. However, due to the recent invention of reinforced concrete, inventions in these two categories overlapped from the early 1870 s to the early 1920s. Thus, inventions in these two categories are combined in this study, following a strictly chronological order, with the category of each development or author noted in each case.

\section{Peter H. Jackson's advancements: 1858-1888}

In the three decades from 1858 to 1888, Peter H. Jackson (1829-1908) obtained at least five patents by developing systems of applying prestress to building construction. Jackson is traditionally cited as the first engineer to patent prestressed concrete structures, even though his patents are not those of an engineer, designed under efficient and rational mechanical criteria. It is possible that he did not understand how civil engineering prestressed trusses worked and may not have known how conventional trusses worked, but those structures inspired his work. He was likely inspired by metal trusses, and if he knew about prestressed trusses, those of Whipple were likely to be in his 
mind because they were among the most popular when he started patenting his prestressed systems. ${ }^{16}$

Two of Jackson's principal merits were to take two construction techniques from bridges (trusses and prestress) and apply them in building construction and on materials that had never been prestressed before: masonry and concrete. In his patents, suggestive sketches and even suggestive intuitions are found, but his descriptions of his inventions lack scientific or technical rigor. The result is that some of his proposed procedures and solutions lack the efficiency of a good prestressed structure.

Born in New York City, Jackson was a member of one of the oldest and most important American industrial families dedicated to the production and sale of iron products. His obituary described him as a "member of a family which has been in the iron fashioning trade here since 1745."17 From 1853 to 1857 and from 1860 to 1874 , he worked with his elder brother James Lander at the company James L. Jackson and Brother and later at the James L. Jackson and Brother Iron Works, both in New York City. Between 1857 and 1860, he left his brother's company to open his own business with an employee: Jackson and Throckmorton, Architectural Iron Works. After the economic depression began in 1873, Peter moved to San Francisco in 1875 , where he founded P. H. Jackson and Co. ${ }^{18}$ All of the iron companies led by Peter Jackson had a common feature: they were focused on architectural elements and building construction. This focus included structural elements as well as ornamental products, fences, and other iron elements for buildings. Whether Jackson had a formal engineering education remains unknown. If he did, he would have been a member of one of the earliest generations of nonmilitary engineers in the United States. Regardless of his education, Jackson was more of an inventive businessman interested in selling a wide range of products than a man of science devoted to understanding and explaining how structures work. Drawing a parallel with the beginnings of reinforced concrete, Jackson could be compared to the Frenchman François Coignet, who was more a chemical industrialist than an engineer ${ }^{19}$ but is still considered the first to have built a house made entirely of reinforced concrete in 1852-1853. Coignet considered "his" invention of reinforced concrete a means of selling his concrete but was not particularly interested in designing concrete structures or deeply understanding how they worked mechanically. Similarly, Jackson would probably more easily think of writing a commercial catalog than a technical paper.

During his first solo industrial adventure, Jackson and Throckmorton, Architectural Iron Works (1857-1860), Jackson developed his first patent related to prestressed structures for buildings: a sidewalk made of prestressed cast iron and wrought iron. ${ }^{20}$ This element may seem to be a humble part of building construction, but reinforced concrete was introduced in the United States in a similar manner. Thaddeus Hyatt and

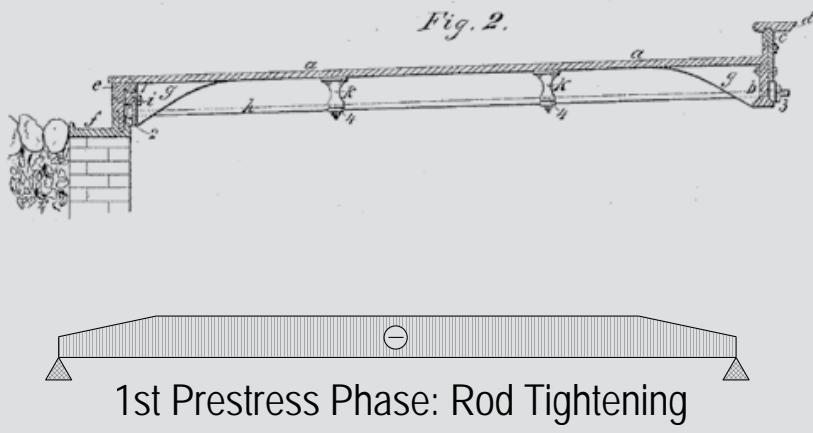

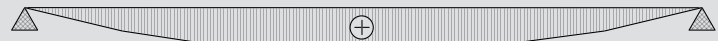

2nd Prestress Phase: Stanchions Tightening

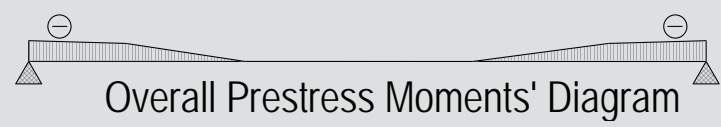

Figure 7. Prestressed cast iron sidewalk as designed by Peter H. Jackson. Patent drawing (top) and moment diagrams on the cast iron plate solely due to prestress (bottom). Source: U.S. Patent 21834 (1858).

Ernest L. Ransome built a number of reinforced concrete sidewalks at the start of their careers in reinforced concrete. Jackson's prestressed metal sidewalk consisted of large plates of cast iron working as the upper chord of a small truss, tie rods of wrought iron working as the lower chord, and metallic stanchions working as vertical posts (Fig. 7). As seen in the description of the patent, Jackson was inspired by trusses and tried to tighten (that is, prestress) the parts of the structure that he thought needed to be tightened. "My said invention consists in so forming the edges of the large iron plates that they receive a wrought iron rod and stanchions which simultaneously make an open truss to support the plate and also straighten out the plate, removing any twist or buckling." ${ }^{20}$

The system was prestressed in two phases. First, the rods (lower chord) were tightened so that the plates (upper chord) were bent upward due to the uniform negative moment (Fig. 7 center). This negative moment due to prestress should be small because it was exclusively resisted by the thin cast iron plate. In the second phase, the stanchions (vertical posts) were placed and tightened so that they pulled together both chords and returned the plates (upper chord) back to a flat position. The second prestress was clearly not correctly designed, as it cancels nearly all of the negative moment achieved in the first prestressing phase (Fig. 7 lower). The design may be considered wrong, not only due to the second phase of counterproductive prestress, but also because Jackson did not take advantage of the entire height of the truss to prestress the structure, as he only placed the stanchions after prestressing the lower chord. Another problem with the design is that the bearings considerably restricted the movement of the system. Many variations on the design are possible to allow it to function correctly, but one of the simplest fixes can be achieved by adapting Whipple's technique: stretch and precompress 


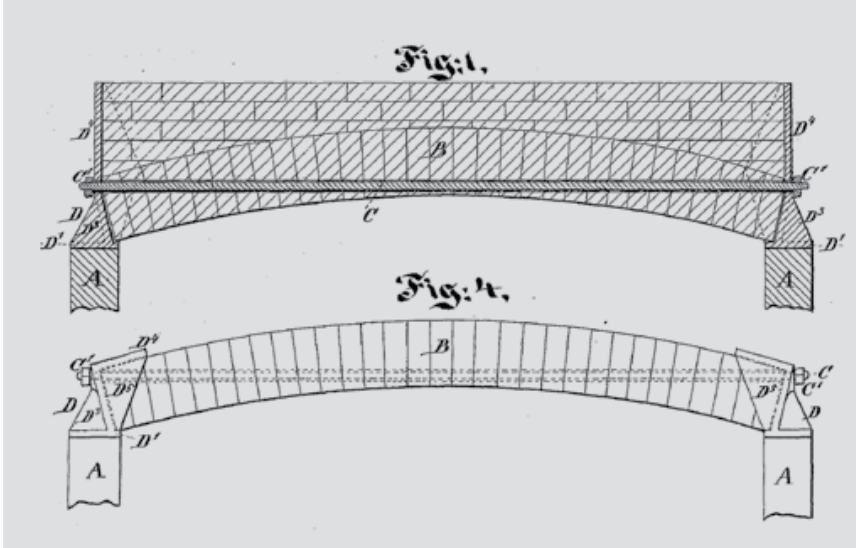

Figure 8. Prestressed masonry arches as designed by Peter H. Jackson Source: U.S. Patent 126396 (1872).

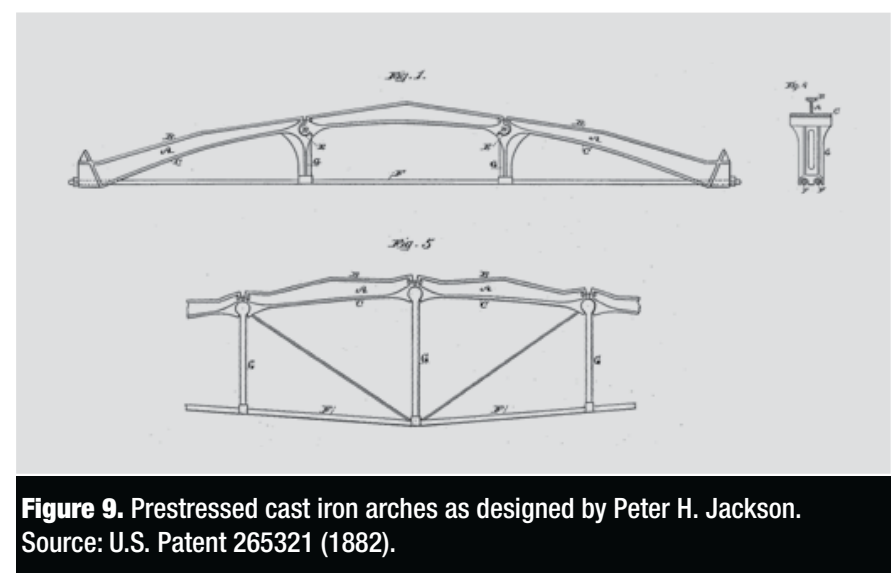

the stanchions so that they cause pretension to both chords. If Jackson had correctly understood Whipple's ideas, he would have been more successful in his design.

In 1872, back at his brother's company (James L. Jackson and Brother Iron Works), Peter Jackson developed one of the patents often cited $^{21}$ as the first achievement in prestressed concrete..$^{22}$ The term girder in the title of this patent is confusing because it may lead the reader to think of a beam or flat soffit element, but this is not the true subject of the patent. In reality, the proposed structure was intended to be an improvement of the classical bowstring arch, also known as a bowstring girder. A peculiar feature of this patent is that it was mainly proposed for masonry construction, but Jackson also left open the possibility of applying the idea to other materials, noting that a "strong and non-conductive material" could also be used, which clearly includes concrete. A conventional bowstring arch constructed of masonry (or concrete) has a disadvantage because the tie rod is vulnerable to fire. Jackson clearly stated several times that fire resistance was one of the main reasons for his invention. However, he also developed the principles of prestressed masonry (in our opinion, without understanding it completely). He proposed two variations of the system, one of an arch with a wall on top (Fig. 8 top) and one simply with an arch (Fig. 8 bottom). The first version is more effective, even though it does not work as an arch or as a beam. Today it would be analyzed using the strut-and-tie method, and prestressing the tie would be an adequate solution (Fig. 8 top). The outcome of the second solution (arch only) is less clear. In this case, the prestress flattens the line of thrust of the arch (Fig. 8 bottom). When the geometry of an arch is already optimized, this correction is counterproductive. When the arch is not correctly designed, the more efficient solution is to correct the geometry without prestressing. Prestressing an incorrectly designed arch is a remedy only when the geometry of the arch cannot be changed. However, that was clearly not on Jackson's mind when he wrote the patent. Beyond this point, both variations of the design have another problem. Masonry (or concrete) is directly in contact with the rod, so the breaking of the bond is necessary for prestressing. However, this should not be difficult because the rod is not deformed.

Once he was on his own in San Francisco (P. H. Jackson and Co.), Jackson developed a series of new patents that were essentially variations of the first two, with some interesting advancements. Unfortunately, these new patents showed few advances in his comprehension of the way in which prestressed structures work. In 1882, he secured a patent ${ }^{23}$ (Fig. 9) for a bowstring girder made of cast iron (upper chord and posts) and wrought iron (lower chord). Again, he presented two versions of his idea.

The main one is a considerable variation of his patent of 1858, which failed to solve two of the main problems: the prestress of the lower chord causes negative moments on the cast-iron upper chord instead of pure tension, and the design does not work as a real truss because the posts do not effectively connect both chords (Fig. 9 top). Surprisingly, it appears that the alternative design he presented, which was only partially described, could have been significantly better because it appears to be an effective truss (Fig. 9 bottom).

From 1886 to 1888 , Jackson patented two inventions strongly resembling the patent of 1872 but also including some interesting new features. In the first patent (Fig. 10 top),the two main innovations are the two-way slabs and the definitive selection of concrete as the material of the upper chord of his prestressed trusses..$^{24} \mathrm{He}$ compared a truss with his system as an indication of his comprehension of the structure. The second patent of this period (Fig. 10 bottom) is similar but with three novel concepts. First, the design included a flat soffit concrete element at least in one direction. Second, there is clear concern about the problem of bonding, a problem partially solved by adding short metallic sleeves at both ends. Finally, the design includes turnbuckles so that the "tension on the tie may be increased and the material acted upon compressed." ${ }^{25}$ Thus, as soon as Jackson began using concrete, he apparently realized that some type of tension loss occurred and suggested a solution to correct it. That is, he was starting to struggle 
against losses. Unfortunately, Jackson was not a rigorous engineer; he could not compete with the technical skills of those who really were engineers, such as Ransome. In the 1880s, Jackson, Ransome, and the architect George W. Percy all lived in California, where reinforced concrete made its earliest advancements in the United States. In 1884, Percy created the Technical Society of the Pacific Coast, where the most prominent engineers of the time gathered. In the mid- to late 1880s, Percy was interested in the ideas of reinforced concrete developed by both Ransome and Jackson. ${ }^{18}$ Percy's relationship with Ransome was much more productive than that with Jackson for many reasons, and this relationship contributed to Ransome's success with reinforced concrete. Percy was closer to Ransome than to Jackson because they were of the same generation, whereas Jackson was 20 years older, and because Ransome was an engineer and acted as a structural consultant for Percy's architectural works. The latter is likely the main reason for their closeness; Ransome not only understood structures but was devoted to their study and to earning his living designing buildings, not generic systems sold in series, like Jackson.

It is possible that Percy's preference for Ransome over Jackson and the fact that Jackson was about 60 years old at that time led Jackson to abandon prestressed concrete. There is evidence that he continued to patent many products and inventions, but none related to prestressing. However, some of his new inventions were related to reinforced concrete and composite floors (concrete joined to steel sheets). Surprisingly, it appears that reinforced concrete (and composite floors) had superseded prestressed concrete in the mind of the inventor of prestressed concrete.

Jackson's work, when viewed as a whole, is difficult to classify into only one age of prestressed concrete, as his inventions have elements of both the first age (lack of engineering rigor) and the second (sometimes mechanically efficient). His inventions can even be categorized as third age because he may have had the intuition of varying loads over time. In sum, Jackson was the pioneer of the idea of prestressed concrete in building construction and the inspiration for the next generation of engineers and inventors.

\section{Thomas A. Lee's advancements: 1890-1894}

Although Jackson ceased developing new systems in the late 1880 s, his inventions were widely known throughout the country thanks to Frank Eugene Kidder, contrary to Billington ${ }^{26}$ and other sources' beliefs. In 1884, Kidder published the first edition of The Architect's and Builder's Pocket-Book, a volume of nearly 600 pages. He published an updated edition every year thereafter, which, in 1908, had grown to1600 pages. Since the 1890 s, this book and others by the same author popularized the reinforced con-

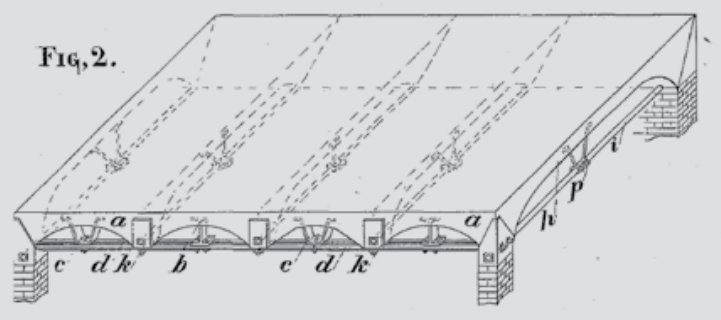

FiG,3.
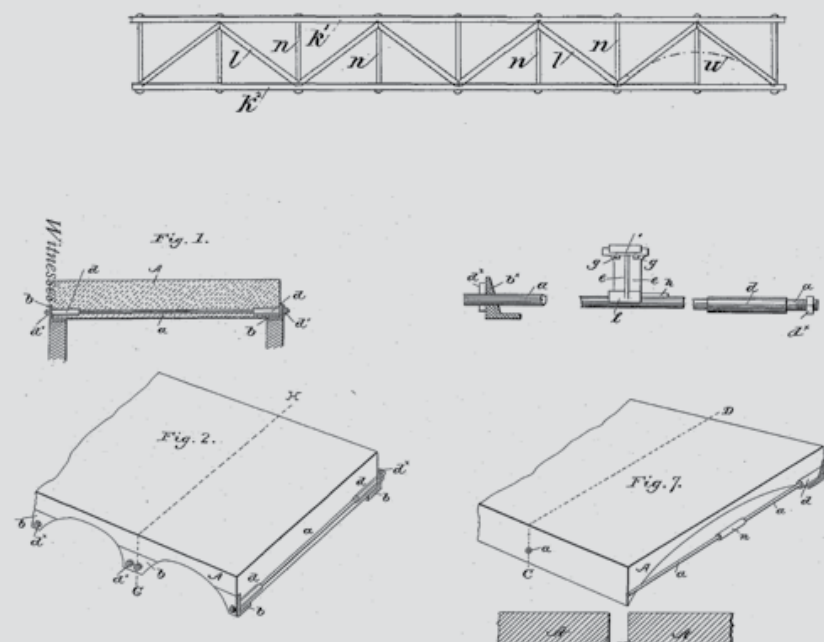

Figure 10. Comparison of a prestressed two-way concrete floor and a metallic truss by P. H. Jackson and prestressed concrete floor by P. H. Jackson Sources: U. S. Patent 366839 (1887); U.S. Patent 375999 (1888).

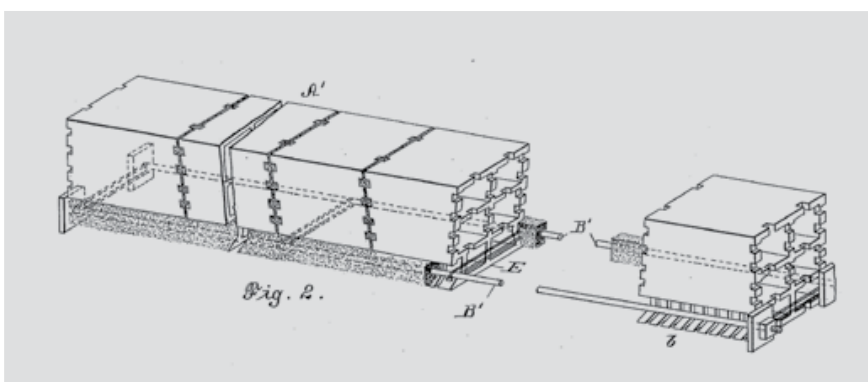

Figure 11. Prestressed segmental beam, as designed by Thomas A. Lee. Source: U.S. Patent 461028 (1891).

crete systems of Hyatt, Ransome, and Jackson.

It is likely that Jackson influenced Thomas A. Lee via Kidder's books or through another channel. Possibly inspired by Jackson's 1872 patent (and maybe also those obtained from 1886 to 1888), in 1890 Lee secured a patent for flat floors made of prestressed masonry of hollow blocks. ${ }^{27}$ Lee thought the system was advantageous mainly because of its fireproof qualities, similar to Jackson in 1872, which is why the blocks in his drawings look like tiles (Fig. 11).

However, in the description of the patent, he insisted several times that any fireproof material may be used (like 
Jackson in 1872), and he mentioned mortar and concrete as possibilities. However, because the blocks are hollow, the average prestress that these floors can withstand is typically quite low by today's standards. In 1892, Lee secured a new patent with several variations, widening the range of structural types that are feasible with his system. In the same year, he also secured two patents for bonding strands made of two or four wires ${ }^{28}$ (Fig. 12). This design was the first application of high-strength steel for a prestressed concrete (or masonry) structure, as well as the first application of a well-bonded stressed reinforcement. Moreover, Lee described a certain type of rudimentary anchoring system that was likely adequate for the low (or medium) average loads on the strands. Altogether, Lee's proposals can be considered the first comprehensive and efficient engineered system for prestressed concrete (or masonry) structures.

Soon after, Lee launched his own business, the Lee Fire Proof Construction Co., which specialized in the application of his system. The company made a considerable fortune, and its systems were soon included in Kidder's book, along with Ransome's and Jackson's systems. Lee's system was imitated for decades in the United States. During the 1940s to 1960s, his system inspired an entire industry, with several companies in nearly every state mainly producing prestressed tile products and precast, prestressed concrete segments. This structural type was known in the mid-twentieth century as Dox Plank. ${ }^{29,30}$

\section{European prestress in the nineteenth century: Who were the real pioneers?}

Meanwhile, in 1888, the German C. F. W. Doehring (also written Döhring) applied for a patent for a system ${ }^{31}$ that is often cited as the first prestressed structural system in Europe and sometimes even compared to Jackson's inventions. ${ }^{32}$ These opinions are not well founded, possibly because the patent exists only in German and few have read it carefully. Doehring's patent is not related to prestressed structural elements, as is believed by even highly respectable sources. ${ }^{21}$ His proposal relates to a system of production of long, thin mortar lattices with triangular section

(Fig. 13 right).

It is difficult to say exactly what size the section of those lattices is, but they can be inscribed in a rectangle no larger than $70 \times 35 \mathrm{~mm}(2.8 \times 1.4 \mathrm{in}$. $)$, possibly even $50 \times$ $25 \mathrm{~mm}(2 \times 1$ in.) (Fig. 14). Even if it were composed of modern prestressed concrete, such a lattice would not be an efficient structural member. However, Doehring obviously never intended it to be so. The title of the patent reveals this: the lattices are a fireproof finish for the lower face of a system of wooden structural floors for which Doehring had applied for a patent earlier that year ${ }^{33}$ (Fig. 14). Although Doehring's lattices are not structural, the patent is notable for two reasons: it is the first known system for the produc- tion of precast mortar (or concrete) elements in which the reinforcement is prestressed, and the text of the patent has a paragraph in which Doehring tries to explain the benefits that prestress provides to concrete:
If two bodies of different elasticities (in this case mortar and iron) simultaneously receive the same ten- sion, the less extensible body [mortar] is broken first; however, the cohesion of the extensible body [iron] is abrogated only after continued exposure to tension. If the extensible body is tightly tensioned (in this case by $T$-screws) and is then simultaneously exposed to the same tension as the inelastic body, both would be simultaneously and almost equally strongly subjected to absolute strength, and they would be broken almost simultaneously. Because a greater force is necessary to simultaneously overcome the cohesive strength of both bodies than the force required to overcome the cohesive strength of each body individually, a greater strength results from the previously mentioned... ${ }^{30}$

Doehring was concerned that the concrete and steel would break in tension at different times because he mistakenly believed that the two materials would be able to withstand a greater force if they broke at the same time. He proposed prestressing the iron so that both materials would break at the same time. It is striking that he did not mention that concrete would be precompressed by the steel when the tension on it was released, possibly because he did not understand that point or did not see an advantage in it. In any case, Doehring could not rationally explain the advantages of prestress, even though he might have had a certain intuition about them. Regardless, he already went quite far in his reasoning if we take into account that a further understanding was unimportant in explaining the invention of a fireproof finish.

The invention of a nonstructural prestressed mortar element has been quoted in books and articles for so many decades as an early step forward in the history of prestressed structures, possibly because of some inaccurate translation or misreading of the first German references. ${ }^{6,7}$ Those two books, along with that of Kurt Billig, ${ }^{5}$ were the only books among the most influential first reference books on prestressed concrete that included significant historical notes on early inventions and applications. Before the release of those books, just before the beginning of the Second World War, prestressed concrete was about to spread through Europe via Germany thanks to the influence of Eugène Freyssinet on some German engineers. In 1937, Ewald Hoyer - probably influenced by Freyssinet ${ }^{3}$ - secured a patent $^{34}$ that made him famous all over Europe. The patent was for a system of precast, prestressed concrete elements using thin wires, such as piano wire. Hoyer's patent cited the earlier patent of Doehring. Perhaps the fame of Hoyer among German-speaking engineers; the poor translations 
from German of the texts of Ritter, Lardy, and Leonhardt; and the fact that Doehring's patent was written in German did the rest to give him more credit than was due for his contribution to prestressed concrete.

To summarize, Doehring's patent can be considered a first-age invention at best, but if we look at it more rigorously, it may not even relate to prestressed structures. However, it is possible that Doehring's patent inspired other German-speaking pioneers, such as Mandl, Wettstein, or Hoyer, and that would be its only relation to the history of prestressed structures.

In 1894, François Chaudy of France brought the continent into the second age of prestressed concrete. He was the first European to engineer and understand an effective solution to prestressing (by posttensioning) a previously hardened concrete beam. ${ }^{34,35}$ His theoretical proposal consisted of casting a beam with a groove along the center of the soffit. Then, a bar placed in the groove is tensioned against cast-iron caps placed at both ends, causing a uniform negative moment (Fig. 15). He considered that the system could also be used for other materials that are weak in tension, such as cast iron.

His ideas were published in a scientific journal, preceded by another short paper of his on the calculation of thin plates of any material. His medium, the Bulletin of the French Civil Engineering Society (Société des Ingénieurs Civils in Paris), was the main publication of this society and thus highly influential. However, the influence of Chaudy on other engineers has not been traced to the present.

Only two years after Chaudy's paper, the Austrian Julius Mandl published two papers ${ }^{36,37}$ with a certain resemblance to it but including several interesting novelties. Mandl's papers were much longer and mainly presented a theoretical attempt to solve the problem of designing reinforced concrete structures. Similar to Chaudy's paper, his work began by studying the case of a reinforced concrete plate. After a complete mathematical description of this case, Mandl followed with a section proposing prestressing the plate by pretensioning the reinforcement made of wires before placing concrete and, after hardening, releasing the prestress. ${ }^{36}$ His idea can be considered the first European proposal to prestress a concrete structure using pretensioned wires. It cannot be dismissed that Mandl may have been inspired by Doehring's patent, published only eight years earlier. However, there is no doubt Mandl went much further because he really understood the idea of prestressing and its structural benefits, which places his proposal in the second age of prestressed concrete structures.

\section{Applications of prestressed con- crete in Europe in the first third of the twentieth century}

This section lists the most frequently cited pioneers of prestressed concrete and checks the value of their proposals.

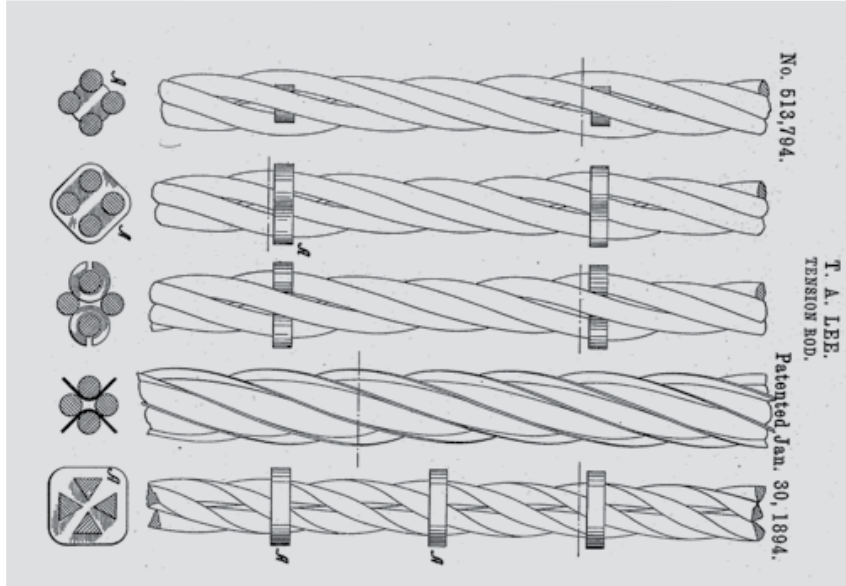

Figure 12. Strands of four wires for prestressed segmental prestressed structures as designed by Thomas A. Lee. Source: U.S. Patent 513794 (1894).
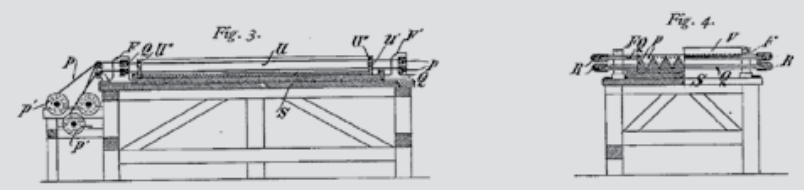

Figure 13. System to precast triangular mortar lattices with prestressed strands embedded, as designed by C. F. W. Doehring. Source: Prussian Patent 53548 (1888). Reproduced by permission of German Patent and Trademark Office.
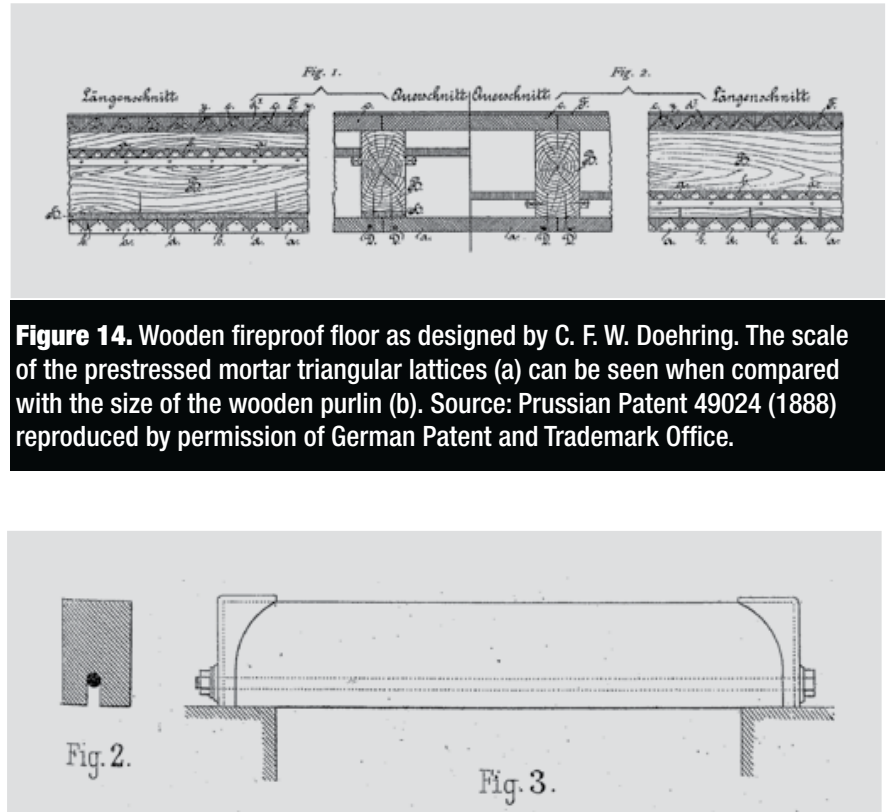

Figure 15. Posttensioned concrete beam as designed by François Chaudy. Source: Reproduced by permission from Conservatoire Numérique des Arts et Métiers (1894).

In France, Charles Rabut built in 1903 (or 1909) a prestressed concrete cantilever spanning $7 \mathrm{~m}(23 \mathrm{ft})$ to carry a street. It was built to enlarge the train station of Saint Lazare without having to give up the width of the adjacent Rue de Rome, which was supported by the cantilever. The 

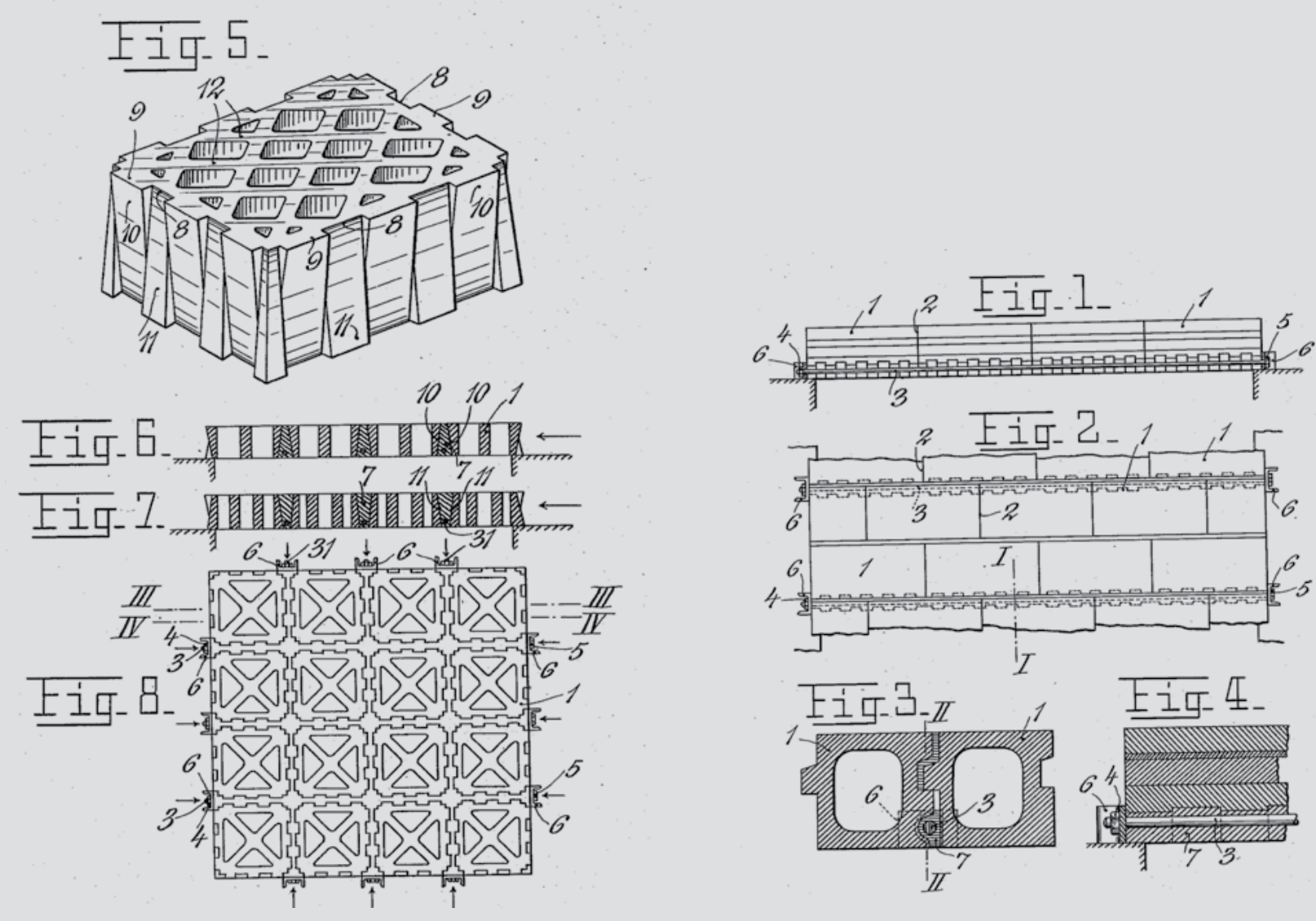

Figure 16. Two-way (left) and one-way (right) posttensioned concrete segmental floor as designed by Jens G. F. Lund. Source: U. S. Patent 1028578 (1912).

cantilever was built in three phases. In the first, the lower part of the concrete beams was placed. Then, the upper reinforcement was prestressed, lifting the cantilever as the dead loads were partially compensated. Finally, the rest of the cantilever was placed. ${ }^{3}$ It is known that Rabut had already built a $3 \mathrm{~m}$ (10 ft) cantilever in the Pereire Boulevard between 1897 and 1900, but whether he used the same method at Saint Lazare remains unknown. Rabut may have thought of prestressing concrete by himself, as he was one of the eminent French scholars on reinforced concrete at the time. It is also possible that he was influenced by others. In fact, some earlier prestressed structures could have influenced him directly or indirectly, including those designed by François Chaudy, Julius Mandl, or the prestressed granite block walls in Finisterre built some two decades before by the Frenchman Armand Considère (an acquaintance of Rabut). ${ }^{3} \mathrm{He}$ may even have been inspired by the considerable number of early American prestressed structures, which were likely known by European scholars.

In 1907, the Norwegian Jens G. F. Lund secured two patents in several European countries related to those of Jackson and Lee on prestressed masonry. The two patents were merged into one when his inventions arrived in the United States. ${ }^{38}$ Lund designed flat soffit floors composed of precast concrete elements that were assembled and posttensioned. The concept may seem similar to that of Lee, but Lund followed two different peculiar building processes. One of the processes, for two-way posttensioned floors (Fig. 16 left), consisted of arranging the precast concrete blocks in rows in two directions, leaving them slightly separated. Tie rods were placed and then mortar poured in the gaps between the rows. Before the mortar completely hardened, the tie rods were tensioned using nuts. As might be expected, the precompression of the concrete achieved in this manner was quite low because mortar in the bidirectional gaps was easily compressed and could even spill out, causing considerable instantaneous losses of prestress.

The other solution, designed for one-way slabs (Fig. 16 right), was slightly different. Tie rods were placed inside long precast concrete ribs that had keys so that the precast concrete blocks could rest directly on them. As the height of the ribs was only half that of the blocks, mortar was placed once the tie rods were pretensioned to complete the height of the slab on the ribs. This system was better than the first system described because the plates at the ends of the tie rods were designed to engage the two adjacent blocks when tightened so that posttensioning was applied on hardened concrete.

Leonhardt ${ }^{7}$ also quoted another interesting proposal of Lund's. The system consists of posttensioning two precast concrete segmental C-shaped beams put back to back and slightly separated so that the tie rod fits in the gap 

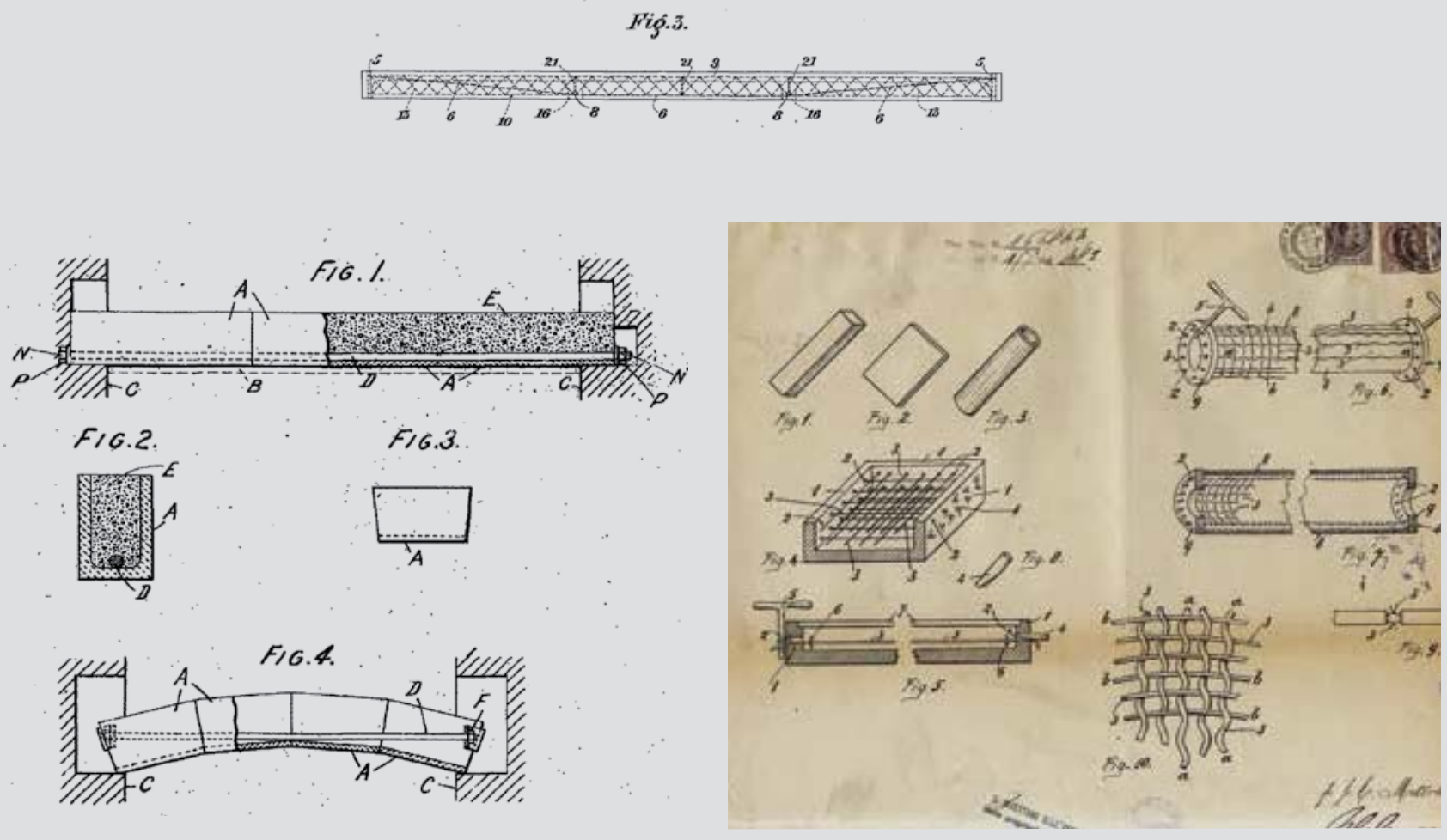

Figure 17. Prestressed concrete systems as designed by Walter Wilson (U. K. Patent 103681, 1917) (top), Frederick Bolton (U.K. Patent 126100, 1919) (bottom left), and Ernesto Mezzetti (Italian patent 166844, 1918) (bottom right). Sources: Reprinted by permission from UK Intellectual Property Office, UIBM, Archivio Centrale della Stato, MICA.

between them. The invention was described by Lund in the Norwegian journal Teknisk Ukeblad. In 1910, two pipe manufacturers, the German David Zisseler and the Swiss Hans Siegwart, produced concrete pipes with spiral wires. However, Zisseler only applied a slight pretension, while Siegwart pretensioned the wires with loads of up to $88.9 \mathrm{ksi}(613 \mathrm{MPa}){ }^{7}$ For that reason, and because Siegwart performed tests showing the considerable interior pressure that the pipes were able to withstand, his can be considered a structure in which prestress is engineered to reach superior performance (second age). Zisseler's pipes, on the other hand, should be considered first-age prestressed structures.

In 1916, the British master of works Walter Wilson secured a patent for precast, prestressed concrete floors and beams. Due to his lack of technical education, the proposal lacks rigor but shows brilliant intuition (first age). His elements (Fig. 17 top) comprise a considerable amount of prestressed reinforcement, made entirely of wires or strand, mostly with polygonal layouts. The system of reinforcement can be summarized as an upper and lower chord, both prestressed and fixed at their ends and tightened by wires wound around them in the shape of braces at 45 degrees. Moreover, Wilson placed a main strand with a polygonal layout parallel to the web already described. The layout of the strand is flat at midspan (of course, placed below), and at the bearings it is brought to the top of the section, inducing a positive moment due to prestress. ${ }^{39}$
In 1918, the British engineer Frederick Bolton secured a patent for a system to prestress U-shaped segmental concrete molds for beams or arches where concrete was subsequently placed ${ }^{40}$ (Fig. 17 bottom left). Bolton's idea was far from optimal. First, he only considered the use of prestress to put together the molds but did not exploit it for the concrete itself. Second, the position of the tie in relation to the shape of the mold is not always beneficial when prestressed. The design may be more or less correct for beams, but in regard to arches, the prestress of the mold may induce tension on the intrados of the arch. His designs, which must be classified as first age, may have been inspired by those of Jackson ${ }^{22}$ or Lund.

In 1918, the Italian Ernesto Mezzetti (Fig. 17 bottom right) patented a procedure to manufacture plates, beams, and pipes with two-way wires, either straight or interlaced, placed at both faces of the elements (except for pipes). ${ }^{34,41}$ Because the wires were at both faces and the average prestress may have been low, this invention is similar to conventionally reinforced concrete. It can scarcely be considered an engineered prestressed structure and should be classified as first age at best.

In 1919, the Czechoslovak Karl Wettstein started producing prestressed, precast concrete joists using thin wires directly bonded to the concrete. ${ }^{7}$ He patented the system a few years later, extending the idea to plates, lattices, and other flat or long elements. Wires were placed at both faces 
of the elements and could be placed all in parallel or in two directions (for flat elements). It is notable that in his Austrian patent, he mentioned that wires may have a minimum diameter of $0.1 \mathrm{~mm}(0.0039 \mathrm{in} \text {. })^{42}$ that is, piano wires used some two decades before Hoyer's famous patent. ${ }^{43}$ The case of Wettstein is similar to that of Mezzetti. Because prestressing both faces is not an effective design, it can scarcely be considered an engineered prestressed structure (first age at best).

In 1923, the Austrian Fritz Emperger described a system for producing pipes of prestressed concrete with spiral wires pretensioned up to $113.9 \mathrm{ksi}(785 \mathrm{MPa}){ }^{7}$ It is difficult to classify Emperger's designs without further information. It is possible that he knew about F. R. McMillan's experiments on creep through Hewett's works and patents, as discussed in the following sections. In any case, Emperger's pipes are at least a second-age structure because he knew the advantages of prestressing concrete by spiral wires.

Another example of the German version of prestressed concrete are the tests performed by Ewald Hoyer in 1925 under the sponsorship of the country council of Magdebourg. He attempted to prestress slabs and beams with pretensioned wires, as others suggested before him, but it appears that he did not succeed. ${ }^{3}$ This effort can be classified as second age.

A last remarkable group of late second-age examples can also be found in Germany, between 1927 and 1938, while Freyssinet was entering the fourth age of prestressed concrete in France. The German engineers Franz Dischinger and Ulrich Finterwalder, working at Dyckerhoff and Widmann, developed several remarkable patents for bridge construction and even built some bridges with their second-age prestressed concrete designs. They must all be considered in that category because they always used iron rods and bands as tendons. These materials are mentioned in the patents, where losses, creep, or shrinkage were never mentioned. The first proposal of that late second-age group was that made by Dischinger in 1927, when he built the Saale Bridge in Alsleben with a design similar to the cast iron bridge over the Arno proposed by Wild and Stephenson some 80 years before. In 1928 Dischinger secured the patent of a system related to his design. In 1934 he secured a new patent for two new systems. ${ }^{44}$ One of the systems is quite similar to that of Whipple in 1841 but with an important difference beyond the material: the upper chord is straight and the lower chord is polygonal. This system, used in one bridge in Aue in 1937, is famous for being the first proposed externally prestressed concrete bridge. The other system consists of inverting the logic of the bridge and transforming it into a suspension bridge by placing a flat soffit in the lower chord and a suspension tendon in the upper chord with a typical shape of parabola. In this case, the prestress of both chords is achieved by tensioning the verticals, which are made of iron. This visionary system became a reference for the construction of suspension bridges for decades. In 1937, Finsterwalder secured two patents. One of those systems, ${ }^{45}$ later used to build the Wiedenbrück Bridge, was inspired in the first of Dischinger's systems described in the patent of $1934 .{ }^{44}$ The other system ${ }^{11}$ is similar to the prestressed timber bridge patented by Long in 1830. As has already been said, Long's version has a slightly better design.

Other prestressed concrete applications may have been developed in non-German-speaking European countries in the first third of the century due to the considerable increase in precast concrete-related patents, but they have not been reported. Most of the designs proposed at that time were likely not engineered prestressed solutions, such as those developed by Wilson, Bolton, Mezzetti, and Wettstein.

In sum, few European engineers appear to have understood at that time the advantages of prestressed concrete, and among those who did, only a few seemed to obtain good results.

\section{The third age: Struggling to minimize losses}

In the first third of the twentieth century, most scholars were unaware of creep in concrete and ignored most of the consequences of shrinkage beyond those related to durability. Engineers were also unaware of the evolution of time-dependent material properties. As pioneering engineers started to explore and apply the idea of prestressing concrete, a few were surprised to find that it was not easy: for some reason, the initial loads reduced dramatically over time. Most of these engineers tried unsuccessfully to solve the problem. Only those who understood the nature of material behavior finally succeeded in efficiently producing prestressed concrete structures. Among those, only two decided to perform tests on their own: the Frenchman Eugène Freyssinet and the Englishman Oscar Faber. That decision gave them considerable advantages over all other prestressed concrete pioneers.

\section{Freyssinet and the idea of prestress as an asset: 1903-1908}

From 1903 to 1904, only some 10 years after François Chaudy had published his paper describing a posttensioned concrete beam, a young civil engineering student, Eugène Freyssinet (1879-1962), assisted in the lectures of the eminent professor Charles Rabut (1852-1925), who is often considered the first ever to teach a course on reinforced concrete, in 1896.

Freyssinet wrote that the idea of prestressing came to 
him in 1903 or 1904 as a student during the lectures of Rabut, which were "devoted, on the one hand to reinforced concrete and, on the other hand, to the systematic study of spontaneous or provoked deflection in structures." ${ }^{26} \mathrm{He}$ also indicated that one of his early visionary moments occurred when he visited the construction site of the cantilever for the Rue de Rome at the Saint Lazare station. ${ }^{3}$ The fact that Rabut devoted some of his lectures to "provoked deflection in structures" means that the professor already had a clear idea of the consequences of "predeflecting" a structure, which is certainly not far from the idea of prestressing.

After his graduation in 1905, Freyssinet kept the idea of deliberately induced deflection in mind as a means of making structures more efficient. That intuition pushed him to begin applying it as soon as possible, and it did so twice from 1906 to 1908. However, only one of those attempts gave encouraging results. That success was achieved when he built the three-hinged Praireal-sur-Besbre Bridge (spanning $26 \mathrm{~m}$ [85 ft]) in 1907 and used induced deformations to remove the formwork (Fig. 18). The idea consisted of placing jacks in the crown hinge and using them to create horizontal thrusts on both half arches. The result was a precompression and slight rotation of both half arches around the abutments' hinges. That caused the half arches to lift from the centering so that it could be stripped more easily ${ }^{46}$ The jacks were then removed, and the three-hinged arch could function normally. This technique was so easy and effective that it soon became internationally used., ${ }^{3,26}$

On that occasion, Freyssinet had only temporarily used induced deformations. Thus, he could see that his idea was feasible without having to deal with long-term behavior, which was unknown to him. At that time, he was working for the contractor François Mercier, who gave him another opportunity to apply his ideas; however, as discussed later, this experience would not be so encouraging.

\section{Verification of shrinkage and the first attempts to control it: 1889-1912}

In the last decade of the nineteenth century, the first important structural systems and patents for reinforced concrete appeared, including those of Joseph Monier, François Hennebique, and Edmond Coignet. After them, many other engineers and businessmen in France, the rest of Europe, and the United States soon hurried to patent reinforced concrete systems. As soon as this occurred, other engineers systematically studied the behavior of this new material. Although studies on the shrinkage of unreinforced cement and other hydraulic materials began long before reinforced concrete was invented, the first relevant report on shrinkage in reinforced concrete, which was written in France by Armand Considère, ${ }^{47}$ only appeared at the end of the nineteenth century. In the first decade of the twentieth century, the number of studies concerning reinforced concrete shrink-
Hinges
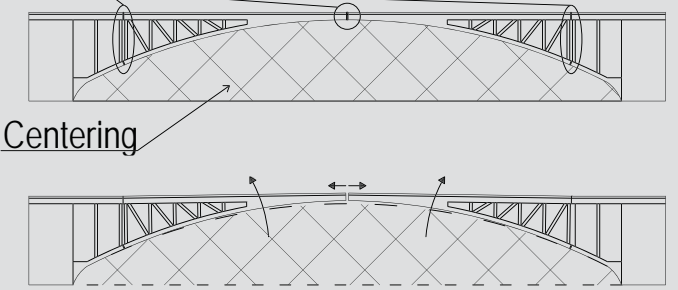

Horizontal thrust at the crown hinge causes up-lift of the two halves of the arch

Figure 18. The decentering process at the Praireal-sur-Besbre Bridge

age increased considerably, and the subject soon became well known and generally accepted among engineers.

In 1906, the German state engineer Mathias Koenen performed a series of tests on prestressed concrete elements with the reinforcement pretensioned before the concrete was placed. ${ }^{7}$ The method used had been previously described by Carl von Bach in 1904. ${ }^{3}$ One of the main aims of those tests was to find an effective means of preventing shrinkage cracks in concrete, as a recent German standard banned any cracking in reinforced concrete. The following year Koenen published the results of the tests, where he indicated that the bars were pretensioned at $58.9 \mathrm{MPa}$ $(8.5 \mathrm{ksi}){ }^{48}$ but he later recognized that most of the prestress force was lost eventually. ${ }^{7,49}$

Meanwhile, in the United States in 1908, Charles R. Steiner of California, possibly inspired by P. H. Jackson or T. A. Lee, patented the first system of prestressed concrete that explicitly tried to counteract the variation in concrete properties over time..$^{50}$ Before Steiner, it is possible that Jackson may have understood the need for retightening in prestressed reinforcement, as he included turnbuckles in his last patent on prestressed concrete. ${ }^{25}$ However, he did not explicitly mention that retightening was intended to compensate for the effects of shrinkage in reinforced concrete, which was not widely known at the time. Approximately 30 years after Jackson's turnbuckles, Steiner did know about shrinkage but not about creep. His system (Fig. 19) consisted of placing rods inside concrete, which would easily be prestressed because of the pockets generated within the concrete for that purpose. The preload was applied in several phases while the concrete was still setting. His idea consisted of applying tension to the rods when concrete had a sufficiently low bond to the reinforcement (low tensile strength) and sufficient compressive strength to withstand the precompression, allowing for the free strain of the rod. After the concrete set, the bond would be reestablished. Of course, the proposal was not effective for many reasons. However, Steiner's patent included four other innovations. He regarded prestressed concrete as an all-purpose material, good for beams, frames with members fixed together, flat slabs, ribbed slabs, cantilevers, tanks, pipes, and retaining walls; polygonal layouts 

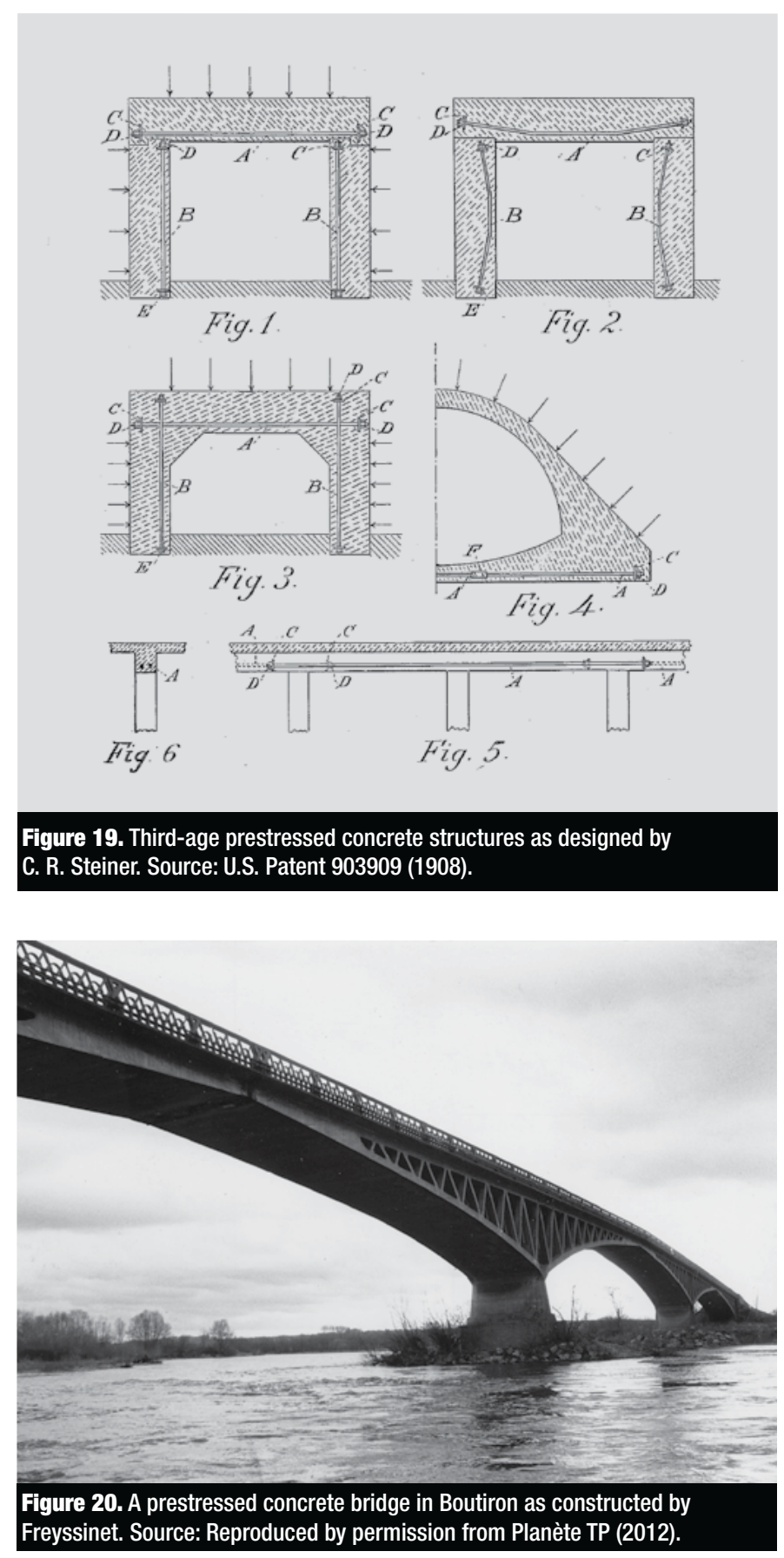

of prestressed reinforcement embedded in concrete, placed where larger tension stresses are expected; overlapping prestressed reinforcing bars; and pockets to protect the ends of the reinforcement after tensioning. ${ }^{50}$ Unfortunately, despite all of his foresight, Steiner's system would never succeed without a proper analysis of the long-term behavior of the material.

In Germany in 1912, Mathias Koenen thought that he had found the solution for the losses that he observed in his tests on prestressed concrete in 1906 and patented a system to apply this solution to beams and plates. ${ }^{49} \mathrm{He}$ thought that the main reason for the losses was shrinkage, which had been "recently discovered," in his words. His idea was to use that same phenomenon to prestress beams and plates.
It consisted of placing the concrete in two phases so that the shrinkage of the second placement (upper half) caused a prestress on the concrete of the first placement (lower half). The idea of using shrinkage to alleviate the effects of shrinkage sounds ingenious, but if it had been effective, it would have caused an adverse flexural moment because the compressive force due to the shrinkage of the upper half is above the center of gravity of the lower section. If that had occurred, Koenen would most likely have caused an unfavorable effect instead of reducing any cracking or losses.

\section{The systematic study of creep: 1905-1937}

Although shrinkage was soon accepted by scientists and engineers, the path to general acceptance was far more complicated for creep. Few studies were conducted on this subject before the 1920s, and most of the researchers on the matter, including Ira H. Woolson (1905), ${ }^{51}$ W. K. Hatt (1907), ${ }^{52}$ Franklin R. McMillan (also MacMillan) (1915), ${ }^{53}$ and E. B. Smith (1916), ${ }^{54}$ lived in the United States. Outside the United States, only Freyssinet was interested in creep before the 1920s.

In 1907, François Mercier, the contractor whom Freyssinet worked for, became completely devoted to an audacious project that the 28-year-old engineer had designed, as only a fantasy, to replace an old, damaged suspension bridge over the Allier River in Boutiron. ${ }^{3}$ This bold design (Fig. 20) in reinforced concrete recalls the iron bridge of Mirabeau in Paris (Fig. 21), which was completed in 1896 by Jean Résal, one of the professors who most influenced Freyssinet at the university. ${ }^{55}$

At that time there were three wooden suspension bridges over the Allier River in the province (département) of Allier: Le Veurdre Bridge, Boutiron Bridge, and Châtel-deNeuvre Bridge. They were all in poor condition. However, the local authorities only had the resources to replace one of them, Le Veurdre, with a new masonry bridge. Mercier saw the opportunity to win a contract to build all three bridges at the cost of the single masonry bridge designed for Le Veurdre. As one might expect, the authorities accepted. The contractor, convinced of Freyssinet's capabilities, decided to put him in charge not only of the design but also of the construction. Freyssinet accepted but decided to build a trial arch to ensure that he would be able to control the construction of such a bridge, which was much more daring than any he had previously built.

The bridge at Le Veurdre was to have three bays that were $67 \mathrm{~m}(220 \mathrm{ft}), 72 \mathrm{~m}(236 \mathrm{ft})$, and $67 \mathrm{~m}(220 \mathrm{ft})$ in length with a span-to-rise ratio of 15 , and all would be spanned by flat three-pinned arches. The trial arch, spanning $50 \mathrm{~m}$ $(160 \mathrm{ft})$, was designed in 1907 and built the next year in Moulins. Because the soil was poor and the construction of 
abutments would have been expensive, Freyssinet decided to build it as a bowstring arch to prevent opening. ${ }^{3}$ The tie was made of a large number of wires fixed to the arch by flat shims. ${ }^{56}$ Freyssinet tried his best to construct a good trial arch with high-strength concrete (40 MPa [5900 psi] after 90 days) and a strict control system for placement, but the results were inconclusive. The arch showed deformations that could not be explained by the theories of the day, which he had learned from his professor, Augustin Mesnager, director of the laboratory of the École des Ponts et Chaussées. Mesnager's criteria coincided with those of the French code published in 1906, ${ }^{57}$ as these were based on his tests. His theory stated that the stress-strain relation was similar in concrete and steel: they are approximately linear in the elastic range and invariant over time. When Freyssinet asked Mesnager about the strange results in his test, the only answer he obtained was that he had committed a series of errors. As he had no time to spend on further investigation, Freyssinet had to concentrate on the design of the Le Veurdre Bridge. ${ }^{3}$ Finally, in 1910, the Le Veurdre Bridge was completed and tested, and it initially performed as expected. However, after a few months, in 1911, worrying deflections appeared and increased as weeks passed. Even if nobody had noticed, Freyssinet realized with anguish that if the deflections were not addressed, the bridge would collapse. Trying to base his reasoning exclusively on the established codes and valid physical properties of concrete, he could not explain the growing deflections. Only when he became determined to question the accepted truths did he begin to find a solution. The results of his previous test and these increasing deflections could be explained if he accepted the hypothesis that the modulus of elasticity of concrete diminished with increasing stress. In any case, understanding the behavior of concrete would clearly not be easy, and the bridge had to be saved rapidly before a disaster occurred. One day at twilight with little traffic on the bridge, Freyssinet and four reliable men placed decentering jacks at the three crown hinges and acted on all of them simultaneously. In this manner, they precompressed all of the arches, lifting them back to the desired position. Then they placed concrete in the gaps and, against the recommendations of the code, disabled the hinges. This operation was successful enough for the bridge to adequately function until its destruction in 1940 during World War II. By moving beyond the nonlinearity of the stress-strain relationship, Freyssinet understood that concrete creeps. He then initiated a series of tests to understand the nature of creep, but he could not complete them due to his professional duties and his service in World War I in $1914 .^{3}$

Among the American studies on creep, the most complete were those of Franklin R. McMillan, a professor at the University of Minnesota. His interest in the properties of concrete started in the early 1910 s and continued until the 1950s. As a result, his work had a significant influence not only on other scholars but also on many engineers, including the prestressed concrete pioneer William S. Hewett. ${ }^{58}$

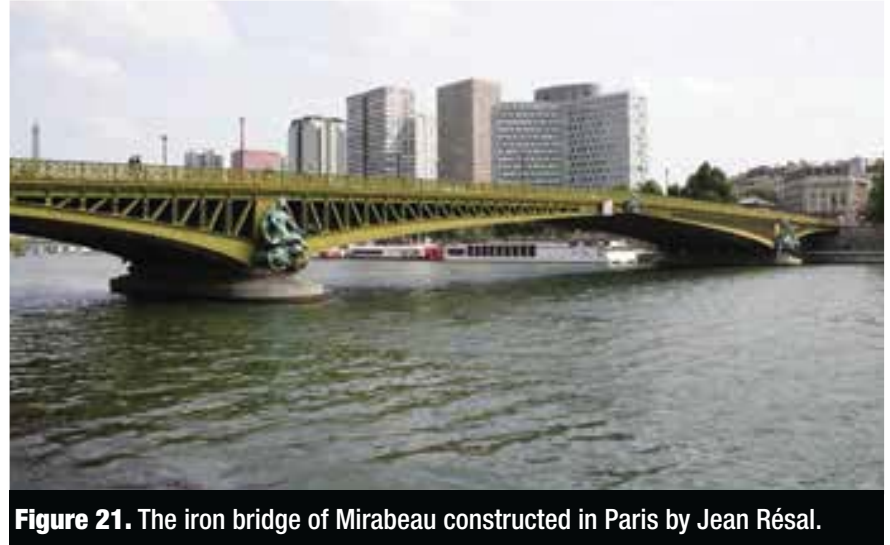

McMillan studied shrinkage and creep, as well as their interaction, but mainly focused on shrinkage..$^{53} \mathrm{He}$ was the first to design systematic tests comparing the deformation of loaded and unloaded specimens, which are essential for measuring the difference between creep and shrinkage.

In the 1920s creep was still largely ignored by European academics, but the Englishman Oscar Faber observed the phenomenon in 1920 while performing tests on prestressed concrete. ${ }^{56} \mathrm{He}$ was both a scholar and a practicing engineer. He became an authority on reinforced concrete when he published the first edition of Reinforced Concrete Design in 1912, which soon became a standard in universities in the United Kingdom. In this book, he elaborated on the properties of reinforced concrete and their implications in design. Beyond discovering creep, Farber is also known for his study on plastic yield in concrete and discussed both topics in an extensive paper ${ }^{59}$ in 1927. That is, Faber made advances in understanding the same two properties of concrete that Freyssinet found mandatory to understand to use prestressed concrete. However, Faber's ideas appear to have been received coldly by the engineering community.

No French scholar was interested in the study of creep in the 1920s or before. However, Freyssinet advanced the field as a result of his experiences at Le Veurdre Bridge in 1911. He considered creep to be the main obstacle to prestressed concrete becoming a practical engineering technique. After the First World War he found the opportunity to study creep when he was commissioned to construct a bridge in Plougastel (Bretagne, France) in 1922. ${ }^{3}$ This bridge was made with three arches, each spanning $186 \mathrm{~m}$ (614 ft), a world record at the time. For this construction, Freyssinet completed a series of tests in 1926-1929 that would lead him to quantify creep. ${ }^{26}$ In such a long bridge, the concrete would experience heavy compression, and those long arches would experience considerable shortening due to creep. Some of Freyssinet's results were published in $1930,{ }^{60}$ but the complete version was published only after his death. ${ }^{61}$ Freyssinet's knowledge of creep was among the most detailed at the time, and he continued to study the subject until his death. Nonetheless, he said that knowledge on creep was far from complete. ${ }^{3}$ 
Sometime after this, William Henry Glanville presented in the United Kingdom the results of a series of tests ${ }^{62}$ that confirmed Faber's statements on creep. Only after Glanville's tests and Freyssinet's papers in the early 1930s did European scientists and engineers start to intensively study creep. That is why most of the prestressed concrete structures built before then were unsuccessful or inefficient.

Even if these first English scholars made significant progress with their studies and increased interest in creep, Freyssinet considered their interpretation of the results to be incorrect because they were not able to understand the difference between creep and elastic shortening. ${ }^{3}$ In any case, the observations of the English could have been sufficient to reach the fourth age of prestressed concrete had they applied their knowledge. However, their contributions remained exclusively theoretical.

Another engineer interested in prestressed concrete and creep at that time was Franz Dischinger in Germany. His studies on creep have been among the most influential since interest arose in the $1930 \mathrm{~s},{ }^{63-69}$ making him one of the most likely candidates to have reached the fourth age of prestressed concrete had Freyssinet not done so.

\section{Solutions to long-term deformations based on lack of bonding: 1919-1937}

While all of the aforementioned concrete properties were being discovered, a new generation of engineers proposed novel solutions to the problem of long-term deformations. Most of the solutions were inspired to some extent by Steiner's patent. ${ }^{50}$ As a result, the lack of bonding between the concrete and the reinforcement played a central role in most of them.

The most eminent engineer of that generation was the English-born bridge contractor William Sherman Hewett, who was established in Minneapolis, Minn. Beginning in 1893 in the American Midwest, he built several reinforced concrete bridges following the recently patented system of the Austrian professor Joseph Melan. ${ }^{70}$ The system consisted of embedding metal sections in concrete arch bridges. Some of Hewett's early composite bridges in the late 1910s were designed by Melan's eminent pupil Fritz von Emperger, one of the pioneers of prestressed concrete. After building a considerable number of bridges, Hewett became interested in the construction of watertight tanks made of reinforced concrete. Hewett's early attempts in 1919 resulted in cracks and leaks in the tanks. Searching for a solution to that problem, Hewett discovered McMillan's studies on concrete shrinkage and creep. ${ }^{58}$ Thus, Hewett had obtained objective data that permitted him to characterize the problems of long-term deformations earlier than Faber and Freyssinet. However, Hewett made only limited use of these data. His lack of technical rigor can be seen by analyzing the patents he secured over the next
15 years. In those patents, improvements appeared only gradually, more as a result of trial and error than as a result of an a priori design and calculation of the structure of the tanks based on reliable data on the long-term behavior of concrete. Hewett was most likely not aware of Steiner's patent ${ }^{50}$ when he secured his first patent in 1921(Fig. 22). ${ }^{71}$ On that occasion he proposed two different systems to prestress the tanks, one based on bonded reinforcement and the other on unbonded reinforcement. Because both systems used conventional steel rods for the prestressed reinforcement, they might have suffered significant losses. Moreover, the construction process was quite complicated. Despite those drawbacks, Hewett's tanks were far better than any conventional reinforced concrete tanks, and the system showed considerable success.

Soon after Hewett's first patent, in 1923, Emperger proposed his system of winding tightened wires around concrete pipes. ${ }^{7}$ In Europe, Emperger had close precedents (Zisseler and Siegwart) other than Hewett's patent. However, that does not mean he was not aware of Hewett's advances; he could have remained knowledgeable of American engineering since his first Melan system bridge installation in the United States together with Hewett. Had Emperger known of McMillan's studies on creep and shrinkage, his proposals in 1923 could have been the first successful engineered design in prestressed concrete that considered the effect of losses. If this task had been achieved, he would have reached the fourth age of prestressed concrete five years before Freyssinet. However, this most likely did not occur. In any case, such speculation is included here only to highlight the fact that all of the necessary elements to arrive at the fourth age of prestressed concrete were already there, waiting for someone to put them together. Hewett, Faber, and possibly Emperger were close to the fourth age of prestressed concrete, meaning that they or other engineers, such as Dischinger, would have reached it soon, even if Freyssinet had not in 1928.

Soon after Emperger's proposal in 1923 in Nebraska, Richard E. Dill secured a patent ${ }^{72}$ for a system to prestress concrete with tendons made of "high-strength steel" pretensioned to near its elastic limit. Dill did not refer to modern high-strength steel wire but simply to rods made of steel (yield strength $f_{y}$ of 30,000 psi [200 MPa]) instead of wrought iron. Before that patent was granted in 1925, he presented another patent that replaced it, correcting errors that he found. The first application is only known through the descriptions included in the new patent, but there is enough detail to understand it. The main difference between them is that in the new patent, the rods are coated with "asphalt (or other material)" 72 to prevent bonding with the concrete. He was the first to propose such a solution (Fig. 23). Dill's concerns regarding bonding to make posttensioning possible were most likely inspired by Steiner's patent,${ }^{50}$ as supported by the manner in which Dill redacted 

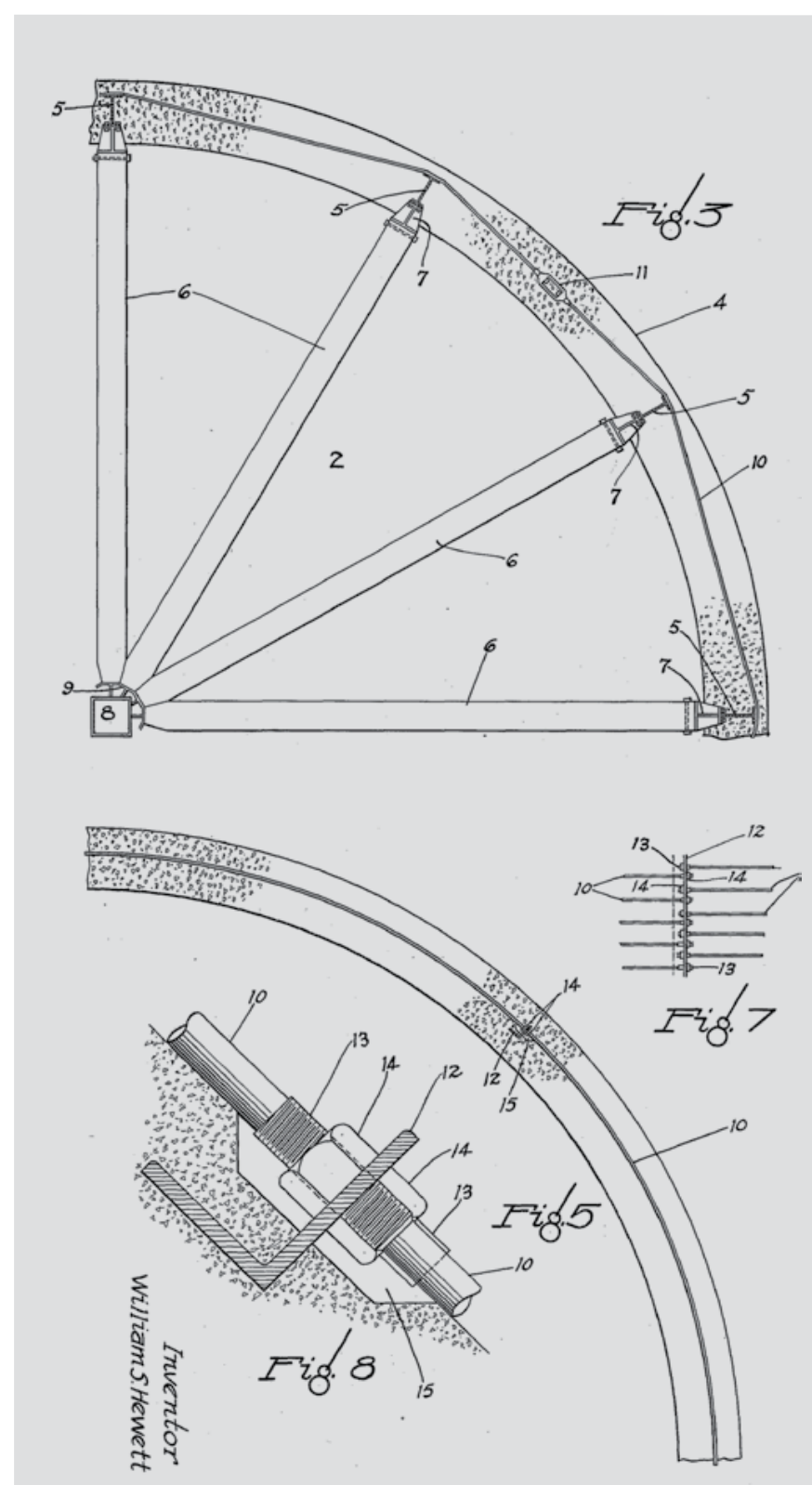

Figure 22. Two systems for prestressed concrete tanks as constructed by W. S. Hewett. Source: U.S. Patent 1413404 (1922).

his patent. The main reasons for the change in the bonding conditions were described by Dill with the following statements: "My afore mentioned application, that of stretching the steel and keeping it stretched during the setting process, as nearly to its elastic limit as is practicable, will not produce the desired result for the following reasons: (1) Concrete, during the setting process, shrinks. The degree of shrinkage is variable. In general, the richer the concrete is in cement the greater the shrinkage. (2) Concrete, after the set is apparently completed, will shrink with loss of moisture. (3) Concrete will shrink under compression at the same rate it will expand under tension." ${ }^{72}$ In point (3), he appears to have described elastic strain more than the effects of creep. Even if Dill used the word flow several times in his patent, it is difficult to say whether he was really aware of creep. In any case, he did not indicate that

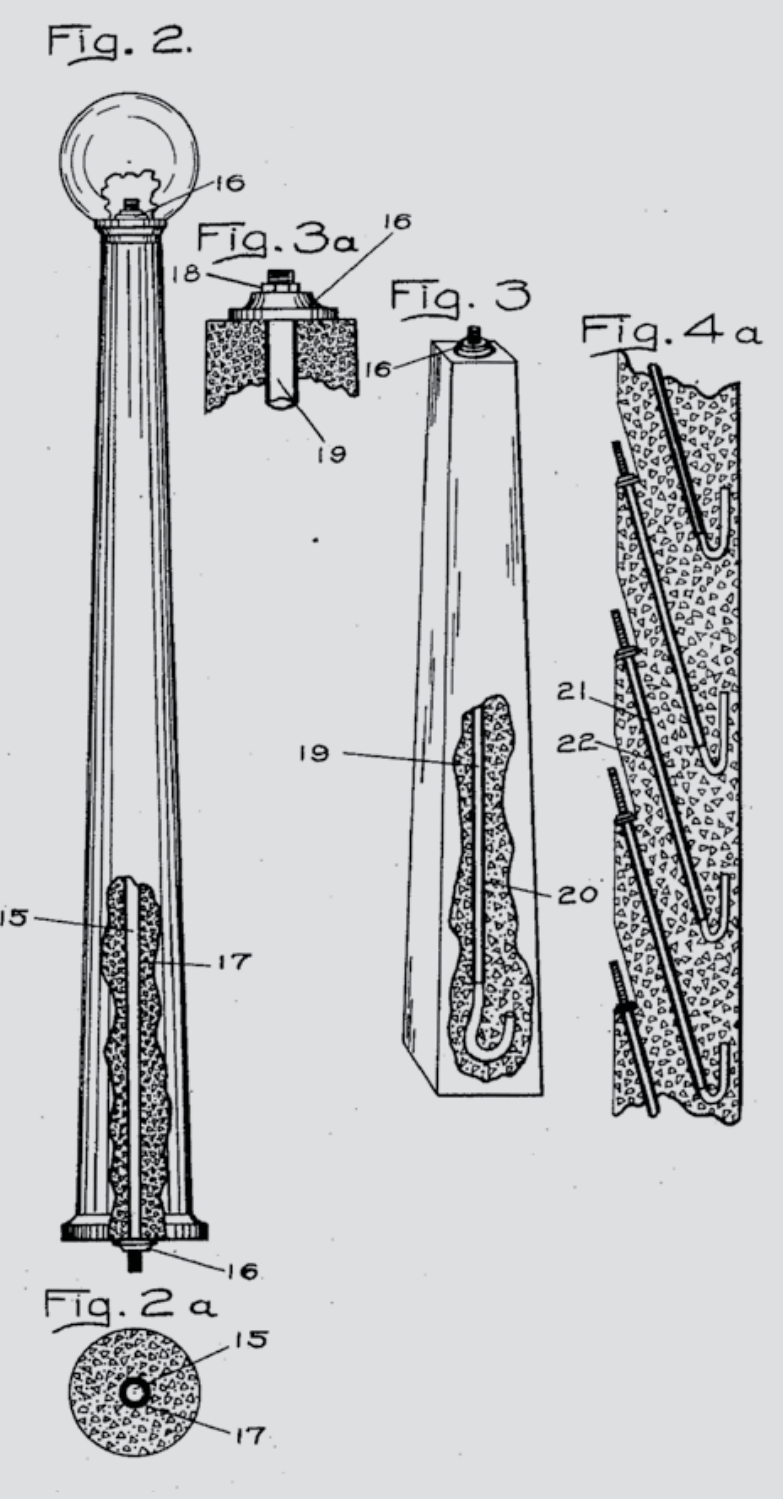

Figure 23. Prestressed concrete with unbonded reinforcement as designed by R. E. Dill. Source: U.S. Patent 1684663 (1928).

he understood its consequences, which would mean that he understood shrinkage and elastic shortening but not creep. In any case, it is remarkable how Dill, like Steiner, saw prestressed concrete as a new material suitable for any application, including bridges, floors for buildings, beams, posts, tanks, and pressure pipes. Two other interesting features are described in the patent but not claimed at the end of it: the possibility of indirect bonding by placing "a wet grout of very rich concrete, or of neat cement"72 inside the holes where the reinforcement is embedded (maybe inspired by Lee) and the possibility of combining several units (most likely precast) to have them work as one element due to the effects of prestressing (maybe influenced by the ideas of Jackson and/or Lee).

While this was occurring in the United States, a similar proposal appeared in eastern Germany (now Poland). In 


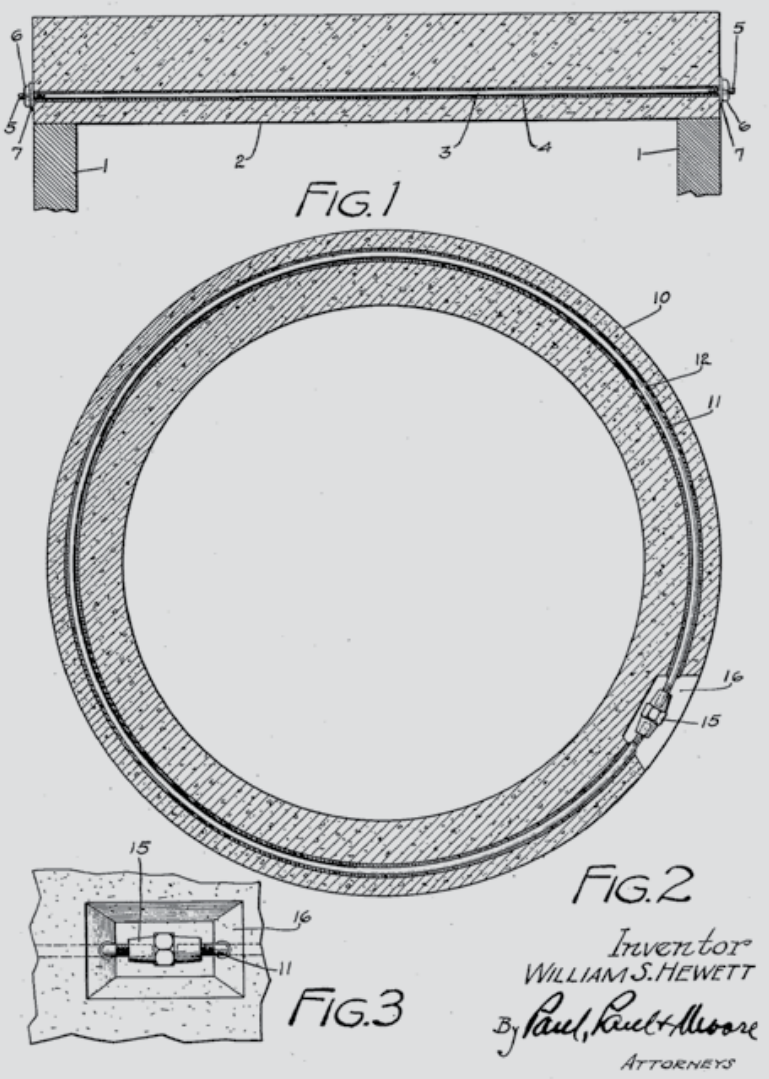

Figure 24. Prestressed concrete tank design with unbonded reinforcement and a handy turnbuckle as designed by W. S. Hewett. Source: U. S. Patent 1818254 (1931)

1927, Richard Färber (also Faerber) secured a patent to obtain unbonded prestressed rods. ${ }^{7}$ His idea consisted of rubbing each rod with paraffin and then wrapping it with a metal sheet or a bandage. An alternative was to place the reinforcement inside a cardboard duct, which was subsequently filled with a "suitable material." Interestingly, Färber mentioned a certain "American system" that had influenced him, which can easily be identified as the work of Charles R. Steiner. ${ }^{50}$ In fact, when the German secured his patent, Dill had not yet obtained his patent; thus, Färber's invention can be considered to be truly original. ${ }^{73}$

In the United States, just before Dill obtained his 1928 patent, Hewett secured in 1927 an enhanced version of his tank system that made construction easier and ensured better tightness. ${ }^{74}$ This patent made two primary improvements: the rods were rubbed with asphalt or equivalent material that prevented steel-concrete bonding, and turnbuckles were added to allow retightening (Fig. 24). The way in which Hewett described the method of avoiding bonding, the fact that he included the possibility of applying the system to other structural elements (such as beams), and the fact that they lived less than 500 miles away from each other makes it likely that Hewett simply copied Dill's idea. However, it does not appear to have created a conflict, as Hewett was a powerful contractor who was becoming more specialized in tank construction every day, while it seems that Dill's patent initially was more valued for the construction of posts. ${ }^{4}$ Conflict could have arisen some years later, as Dill licensed his patent to the Preload Corp. to build tanks, ${ }^{4}$ but no detail is known on that. One last patent of Hewett shows how he engineered his tanks. ${ }^{75}$ In 1935 he secured a device to control the tension in the prestressed rods to avoid guesswork ${ }^{75}$ in tightening operations. If before that date Hewett had tensioned his rods only by guessing, he clearly did not estimate losses, even if he had some knowledge of their existence from McMillan's work. ${ }^{58}$ This places his inventions in the third age of prestressed concrete.

Unlike Hewett's, Dill's and Färber's inventions appear close to the fourth age because they both correctly addressed the problem of shrinkage; however, neither was based on a solid awareness of creep.

\section{The fourth age: Effective prestressed structures through losses}

\section{Freyssinet devotes his life exclusively to prestressed concrete: 1928}

Once Freyssinet's tests for Plougastel were well advanced and he felt able to control the consequences of creep, he made a dramatic decision in October 1928 that would change his career and the history of construction. He staked everything on the study of prestressed concrete. At that time, the construction of Plougastel would continue for another two years. Plougastel can be considered the first prestressed structure of the fourth age because it was finished by prestressing the crown of the arches-like in Le Veurdre-based on Freyssinet's knowledge of the long-term behavior of concrete. For several years, he tried to convince the contractor he worked for, Claude Limousin, to bet on his idea, but he had no success. As a consequence, he felt compelled to undertake this adventure on his own. ${ }^{3}$ In September, only a month before he determined to change his career, he had published his first paper explaining the value of prestressed concrete. ${ }^{76}$ In November, together with Jean Seailles, he secured the first in his series of oft-imitated patents: concrete prestressed with wires. ${ }^{77}$ From a certain perspective, Freyssinet's patent was not really a new invention; many others before him (mainly Germans) had thought to embed wires under tension in precast concrete members: Doehring, ${ }^{31}$ Mandl, ${ }^{36}$ Lund, ${ }^{37}$ Zisseler and Siegwart, ${ }^{7}$ Mezzetti, ${ }^{40}$ Wettstein, ${ }^{41}$ and Hoyer, ${ }^{3}$ among others. However, Freyssinet and Seailles had at least two qualitative differences from their predecessors. First, they knew where to place the prestressed reinforcement to obtain a perfectly engineered prestressed concrete element, and second, they could understand and quantify the losses 
due to creep and shrinkage, account for them, and design effective solutions. Freyssinet and Seailles' patent (and an addendum made in 1930) showed considerable detail and demonstrated their deep understanding of the matter (Fig. 25). Only five features of this complete and detailed patent are mentioned here as examples:

- the recommendation to use high-quality concrete (one of his very important contributions) and very high strength steel (wires)

- a variety of methods to tension the wires

- the possibility of using polygonal layouts

- the possibility of precasting several long elements on only one beam of wires followed by cutting them to the length desired

- deeming shear reinforcement to be unnecessary because of the precompression of the concrete

\section{The early popularization of prestressed concrete led by Freyssinet: 1928-1936}

After securing his patent, Freyssinet decided to find a contractor that would be interested in the idea. He soon found the Société FOLCRUM (Force et Lumière Electriques), one of the largest French electrical utilities of the day. FOLCRUM had the main goal of designing a new type of utility pole because reinforced concrete poles were proving to be of poor quality. The utilities agreed to assume half of the risk of the project, with the other half to be assumed personally by Freyssinet. As he soon understood, the project was not particularly well suited for prestressed concrete, but the aim was to produce nearly 20,000 units of 12 to $16 \mathrm{~m} \mathrm{(39}$ to $52 \mathrm{ft}$ ) poles per year. The project started at the end of 1929. For the venture to be profitable, he concluded that a better solution was to make an extremely high-quality product. He succeeded: in the end, the concrete had a strength of nearly $100 \mathrm{MPa}(14,500 \mathrm{psi})$ and the poles had walls as thin as $18 \mathrm{~mm}(0.7 \mathrm{in}$.) and were able to withstand 1 million test cycles under service loads without cracking. However, achieving that quality and inventing an entirely novel industrial production logic took five years and ruined him financially. Moreover, the Great Depression began in 1929 and lasted more than a decade. The economic situation and the absence of an effective business plan caused all of that effort to be wasted. By 1933, the project was a complete failure. Freyssinet nearly gave up on prestressed concrete. ${ }^{3}$

As he witnessed the project slipping away in 1933, he looked unsuccessfully for new ways to move his idea forward. However, two of his initiatives of that period would prove important years later. First, he published a
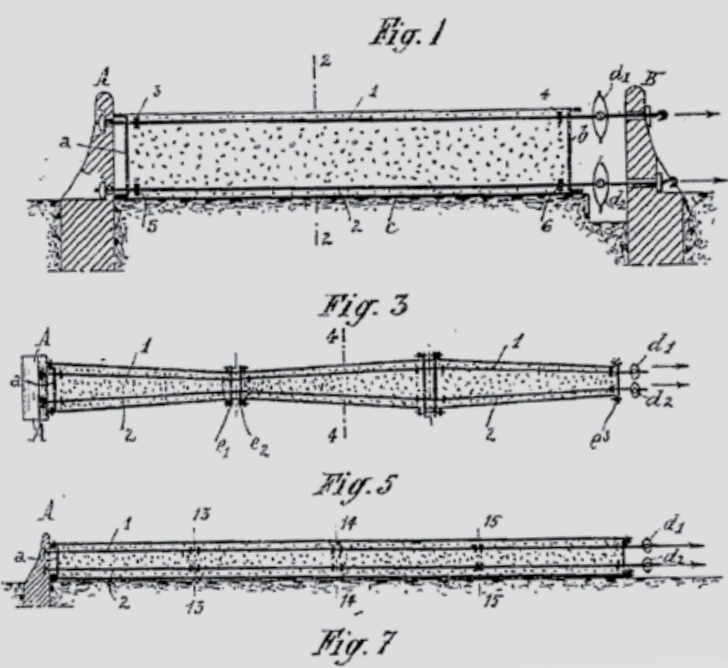

Figure 25. A prestressing system for precast concrete elements as designed by E. Freyssinet and J. Seailles.

Source: Reproduced by permission from French Patent 680547 (1930).

paper to explain his ideas. ${ }^{78}$ This paper is considered to be the foundation of prestressed concrete as it is understood today. Second, in Germany, he built the first prestressed concrete beam of the fourth age. This beam, spanning $20 \mathrm{~m}(66 \mathrm{ft})$, was built for a test performed for the leading German contractor specializing in reinforced concrete, Wayss and Freytag. The technical director, Karl Walter Mautner, an Austrian Jew, personally supervised the test. His interest in Freyssinet's ideas was one of the main reasons that Wayss and Freytag performed it. ${ }^{56}$ The results were excellent, but the company did not show real interest in the technology until three years later, possibly because Freyssinet's patent was not granted in that country until 1935 .

In the last months of 1933, Freyssinet was desperate and thought that only a miracle could save his project. Then an exceptional opportunity presented itself: the recently finished maritime station of Le Havre was sinking, and it was becoming an affair of state in France. An architect related to the project offered Freyssinet the opportunity to intervene, as all previous attempts to save it had failed. Freyssinet knew that he would most likely not succeed, but he may also have thought that he would have no better opportunity to apply his system on a large scale without dispute. He accepted the challenge and applied the idea of prestress as much as possible. He built piles of segments that had been assembled using prestress forces. The piles were prestressed to the caps. The caps were prestressed to the foundations. All of this work was completed under enormous pressure and at an accelerated pace, but it succeeded in stabilizing the building. This was, in the eyes of all of France and other parts of Europe, a definitive confirmation of prestressed concrete as a powerful and useful technology. ${ }^{3}$ 


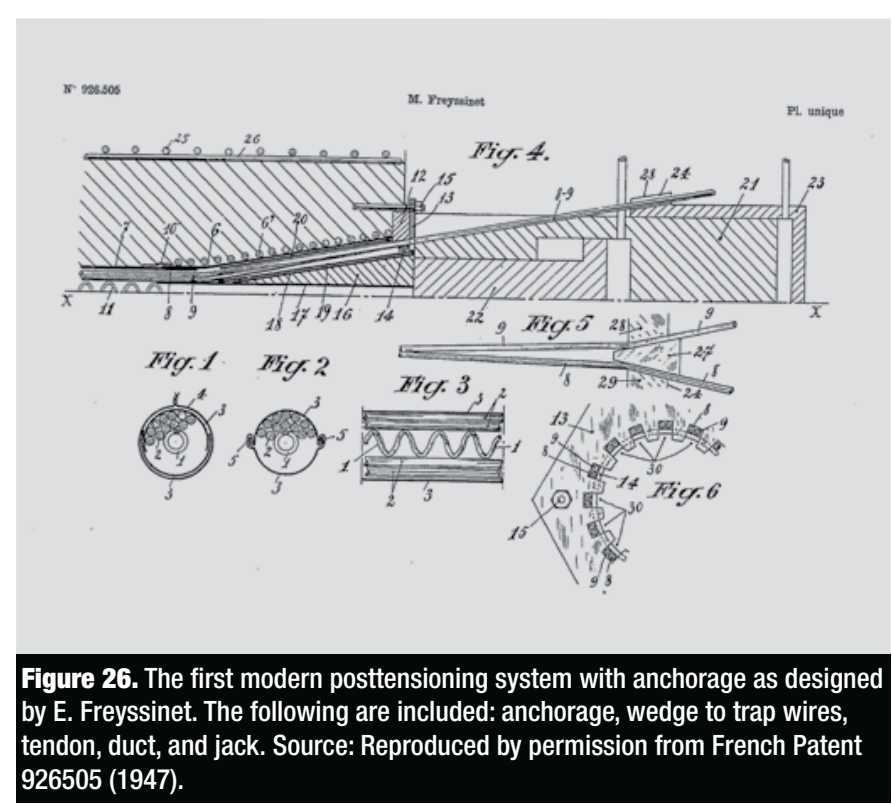

The rescue of the maritime station was soon followed by the publication of a paper and by the first book on prestressed concrete as we know it today. ${ }^{79}$ Those publications and other papers and conferences in those first years and during the following decades were essential for prestressed concrete to become widely used.

Soon after, from 1935 to 1939, Freyssinet worked in OuedFodda, Algeria, on the construction of a dam. There, he built the first prestressed concrete dam and the first bridge made of flat soffit prestressed concrete beams. In the same period, he performed a new test for Wayss and Freytag that was similar to the first, this time in Stuttgart (1936). Finally, this second test and the earlier successes achieved with the technique encouraged the German contractor to build the Oelde Bridge in 1938, the first modern prestressed concrete bridge in Europe. That bridge definitively proved to German engineers that Freyssinet's proposals were meaningful. ${ }^{3}$ After that, several other bridges inspired by this work were built.

\section{The expansion of prestressed concrete in Europe due to the war: 1937-1940}

In 1937, the German engineer Ewald Hoyer, who had failed a decade before in his attempts with prestressed concrete beams at Magdebourg, ${ }^{3}$ was now encouraged by Freyssinet's successes. That year, in Austria and Germany, he secured four patents ${ }^{43}$ on precasting prestressed concrete beams and similar elements using procedures inspired by those described in Freyssinet's patent, ${ }^{77}$ which was applied for in Germany in 1929 and granted in 1935. If German magistrates did find that Freyssinet's patents invalidated several of Hoyer's patent applications, they granted them anyway. Such decisions were starting to be influenced by considerations of the impending war. German territorial expansion during the war did much to popularize Hoyer's patents, which became widespread in Europe during and after the war. ${ }^{3}$ Beyond this plagiarism, some of Hoyer's proposals appear to be original, particularly some of those related to wire bonding.

The war had other important consequences. In 1937 in the United Kingdom, Archibald Kirkwood-Dodds was the director of the engineering firm L. G. Mouchel and Partners, a pioneer in reinforced concrete. He proposed the creation of a subsidiary called the Pre-Stressed Concrete Co. Ltd. to develop the ideas of Freyssinet. The company did not become truly operational until 1939, when KirkwoodDodds brought to England the expert K. W. Mautner, the former director at Wayss and Freytag who had witnessed Freyssinet's first tests in Germany in 1933. Due to his Jewish ancestry, Mautner had been put aside from the directorate of Wayss and Freytag some years before he fled to the United Kingdom and had even spent some time in prison in Germany for the same reason. ${ }^{56}$

In August 1939, Freyssinet secured possibly his most famous and definitive patent: the complete system to posttension concrete members (Fig. 26) ${ }^{80}$ The system included everything necessary to make possible what we now understand as posttensioned concrete: the anchorage device, the duct, the jack, and the tendon, which was designed with parallel wires rather than the strands used today. In June 1940 the Germans invaded France. Subsequently, Alfred Tony Jules Gueritte, a Frenchman, fled to Great Britain and, on August 13, 1940, secured a direct plagiarism of Freyssinet's patent in his own name. ${ }^{81}$ Two weeks later, on August 27, the Pre-Stressed Concrete Co. led by Kirkwood-Dodds and Mautner presented a similar patent including only slight variations. ${ }^{82}$ Freyssinet applied for his patent in the United Kingdom the next year, in February, ${ }^{83}$ before the other two patents were granted. Nevertheless, both plagiarized patents were granted in November 1941, and Freyssinet's originality could not be verified until after the war. The legal uncertainty due to the German invasion probably led Freyssinet to secure a new version of his patent in France in October $1940 .^{84}$ If this had been the case, Freyssinet's French patent of $1939^{80}$ would have lost its priority to applications submitted by Gueritte ${ }^{81}$ and the Pre-Stresssed Concrete Co ${ }^{82}$ in the United Kingdom during the war. The new version of the patent for which he applied was similar to the first patent (applied for in 1939) but was slightly less ambitious. This second patent was granted only two years after the application, while the first and original was granted in 1947, well after the war, when the priorities were resolved.

Those early copies or near copies by Hoyer, ${ }^{43}$ Gueritte, ${ }^{81}$ and Kirkwood ${ }^{82}$ illustrate the power of Freyssinet's influence at the time. He might not have realized it at the beginning, but his inventions were most likely considered war technology and were copied through espionage. Curiously, in 1939, Freyssinet had also patented his invention of flat jacks, which are essential for the construction of 
prestressed concrete structures without tendons. ${ }^{85}$ However, nobody copied this idea, probably because it was not understood, and, to a certain extent, it is still not understood today. At that time and for several decades, most people thought that Freyssinet had invented (or reinvented) prestressed concrete and that this technique consisted of prestressing steel tendons connected to concrete. This perspective is clearly too reductionist. He actually developed modern prestressed concrete (fourth age prestressed concrete) and promulgated the idea that prestressing tendons are not the only means of applying prestress to concrete.

Despite the plagiarism, at least two remarkable, rigorous, and original technical contributions were made at that time. The first was by the Austrian engineer Fritz Emperger in 1939, when he secured a patent for partial prestress, ${ }^{86}$ which would later be energetically defended by Paul W. Abeles, a Jewish compatriot of Emperger who fled to Great Britain. The second contribution was made by the Belgian Gustav Magnel. He studied the relaxation of steel and its influence on prestressed concrete, ${ }^{87}$ as well as buckling in prestressed concrete elements. ${ }^{88}$

\section{The first wave of prestressed concrete advancement in Europe after the war: 1940-1950}

In addition to those first copies, some less mechanical imitations appeared. Even if Freyssinet had the idea, nothing could stop other engineers from using it and introducing legal variations into their own patents. By reviewing the main posttensioning systems developed at that time, one can see where and how the ideas of Freyssinet took root. Table 1 shows some of the main patents published in Europe from the beginning of the war. Some important American patents are also included in Table 1, but our survey in the United States has not been exhaustive.

These variations are interesting and beyond the anchoring system proposed by Freyssinet, three other important families of systems were used at the time: anchorages (Freyssinet), a precompressed steel nucleus (Schorer), ${ }^{89}$ overlapped loops (Lesage), ${ }^{90}$ and straight bars and nuts (the older system). In addition to the four main families, other singular systems are included in the table.

Table 2 lists the main books on the subject. No original American books were found on prestressed concrete in that period. It is thought that the books used in the United States at that time were mainly those published in the United Kingdom.

\section{The second wave of prestressed concrete expansion in Europe after the war: 1950-1955}

In 1948 the American contractor Preload Co. built the first modern prestressed concrete bridge in the United States, the Walnut Lane Bridge. The project was designed and led by the Belgian Gustav Magnel, a visionary engineer inspired by Freyssinet's advances in the early and mid1930s. This construction and the fact that Magnel was a persuasive professor definitively convinced several American engineers of the advantages of this technique. ${ }^{26}$ From that moment on, and particularly after the first U.S. conference on prestressed concrete in 1951 at the Massachusetts Institute of Technology, prestressed concrete structures flourished in the United States.

Table 3 shows some of the main patents, and Table 4 lists the books published in major European countries. Some important American books and patents are also included, but the survey has not been exhaustive in the United States. The last table is devoted to the most important congresses (Table 5).

\section{Conclusion}

The four ages approach to the history of prestressed concrete is useful to clarify the nature of advances reached by the pioneers who contributed to this technique. Using this approach supports the following conclusions.

Our review motivates a revision of the early history of prestressed concrete. The contributions of some designers, including Doehring, Lund, Mezzetti, Finsterwalder, and Hoyer appear less significant than previously portrayed, while those of others, such as Jackson, Lee, Chaudy, Mandl, Rabut, and Emperger appear more significant. In addition, the importance of pioneers of already high reputation, including Hewett, Dischinger, and Freyssinet, has been clarified.

Although most of our conclusions regarding the importance of Freyssinet are not new, putting his work in the context of other pioneers demystifies it while showing his importance to the field of prestressed concrete.

The idea that prestressed concrete would not exist without Freyssinet is refuted. The first engineered prestressed structures were made of timber in the United States 70 years before Freyssinet first had the idea, and the first prestressed concrete structure appeared approximately 30 years before him, also in the United States. Moreover, the fourth age (definitive stage) of prestressed concrete structures would have been reached at nearly the same time had it not been advanced by Freyssinet. However, if that had happened, prestressed concrete would possibly have had little importance relative to reinforced concrete, just as had occurred more than a century earlier with other occasionally prestressed materials. From this perspective, we see that Freyssinet's main contribution was not the invention of prestressed concrete but the fact that he looked at prestressing as a beneficial technique to be used in any 
Table 1. Early posttensioning systems in Europe and the United States, 1940 to 1950

\begin{tabular}{|c|c|c|c|c|c|c|c|}
\hline $\begin{array}{l}\text { Country of } \\
\text { Priority }\end{array}$ & $\begin{array}{c}\text { Patent } \\
\text { consulted }\end{array}$ & $\begin{array}{l}\text { Priority } \\
\text { Date }\end{array}$ & Publication & Inventor(s) & Applicant & System & Duct; Jack \\
\hline France & FR 926505 & 1939 & 1947 & E. Freyssinet & n/a & 1 & $\mathrm{D} ; \mathrm{J}$ \\
\hline United Kingdom & GB 541437 & 1940 & 1941 & $\mathrm{n} / \mathrm{a}$ & A. T. J. Gueritte & 1 & $D ; J$ \\
\hline United Kingdom & GB 541160 & 1940 & 1941 & $\mathrm{n} / \mathrm{a}$ & $\begin{array}{l}\text { A. Kirkwood and Pre- } \\
\text { stressed Concrete }\end{array}$ & 1 & No D; J \\
\hline France & FR 870070 & 1940 & 1942 & E. Freyssinet & $\mathrm{n} / \mathrm{a}$ & 1 & $\mathrm{D} ; \mathrm{J}$ \\
\hline United States & US 2328033 & 1940 & 1943 & H. Shorer & $\mathrm{n} / \mathrm{a}$ & 2 & None D; J \\
\hline United States & US 2319105 & 1942 & 1943 & K. P. Billner & $\mathrm{n} / \mathrm{a}$ & UNC & $\begin{array}{l}\text { None D; } \\
\text { No J }\end{array}$ \\
\hline Belgium & FR 892133 & 1943 & 1944 & $\begin{array}{l}\text { A. Blaton and E. Blaton } \\
\text { (G. Magnel) }\end{array}$ & $\mathrm{n} / \mathrm{a}$ & 1 & D; No J \\
\hline France & FR 980796 & 1943 & 1951 & H. Lossier & $\mathrm{n} / \mathrm{a}$ & UNC & $\begin{array}{l}\text { None D; } \\
\text { None J }\end{array}$ \\
\hline France & FR 984471 & 1943 & 1951 & $\mathrm{n} / \mathrm{a}$ & SGTM & 2 & None D; J \\
\hline France & FR 916990 & 1945 & 1946 & $\mathrm{n} / \mathrm{a}$ & SGTM & 2 & None D; J \\
\hline Belgium & FR 954204 & 1946 & 1949 & G. Lesage & n/a & 3 & $\begin{array}{l}\text { None D; } \\
\text { None J }\end{array}$ \\
\hline Italy & Unknown & $\begin{array}{l}\text { Un- } \\
\text { known }\end{array}$ & 1948 & R. Morandi & Unknown & 1 & Unknown \\
\hline $\begin{array}{l}\text { United Kingdom } \\
\text { Belgium }\end{array}$ & FR 1010934 & 1949 & 1952 & $\begin{array}{l}\text { A. Blaton and E. Blaton } \\
\text { (G. Magnel) }\end{array}$ & $\mathrm{n} / \mathrm{a}$ & $\mathrm{n} / \mathrm{a}$ & No D; J \\
\hline Switzerland & CH 276637 & 1949 & 1951 & BBR & BBR & $\mathrm{n} / \mathrm{a}$ & D; No J \\
\hline Switzerland & CH 279562 & 1949 & 1952 & BBRV & BBRV & 1 & No D; J \\
\hline United Kingdom & GB 664458 & 1949 & 1952 & D. H. Lee & McCalls Macalloy & 4 & № D; № J \\
\hline United Kingdom & GB 683890 & 1949 & 1952 & D. H. Lee and G. E. Kee & McCalls Macalloy & $n / a$ & No $D ; J$ \\
\hline United States & US 2609586 & 1949 & 1952 & R. M. Parry & $\begin{array}{l}\text { Raymond Concrete Pile } \\
\text { Company Ltd. }\end{array}$ & 1 & No D; J \\
\hline
\end{tabular}

Note: BBR = M. Birkheimer, A. Brandestini, and M. R. Ros; BBRV = M. Birkheimer, A. Brandestini, M. R. Ros, and K. Vogt; (Actual inventor); $1=$ anchorage system; 2 = precompressed steel nucleus; 3 = overlapped loops; $4=$ bars and nuts; $\mathrm{D}=$ systems that include the description of a duct; $\mathrm{J}=$ systems that include the description of a jack; $\mathrm{n} / \mathrm{a}=$ not applicable; No $\mathrm{D}=$ systems that do not include the description of a duct; No $\mathrm{J}=$ systems that do not include the description of a jack; None $\mathrm{D}=$ systems where a duct is not necessary; None $\mathrm{J}=$ systems where a jack is not necessary; SGTM = Société Générale de Travaux de Marseille; UNC = systems that cannot be classified in the four main families.

structure, no matter its material, shape, or function. Beyond being the first to drive prestressed concrete to its fourth age, Freyssinet is the intellectual father and the primary engineer to popularize prestressed structures. However, he left an additional implicit message: understanding the materials of a prestressed structure is essential to the quality of the design.

\section{Acknowledgments}

The authors would like to thank Antoine E. Naaman for encouraging them to publish this paper. The authors would also like to thank Maney Publishing for the valuable images of Robert Stephenson's and Charles H. Wild's works. 


\begin{tabular}{|l|l|l|l|}
\hline \multicolumn{1}{|c|}{$\begin{array}{c}\text { Publication } \\
\text { country }\end{array}$} & $\begin{array}{c}\text { Publication } \\
\text { date }\end{array}$ & \multicolumn{1}{|c|}{ Author(s) } & \multicolumn{1}{c|}{ Title } \\
\hline France & 1936 & Eugène Freyssinet & Une Révolution dans les Téchniques du Béton \\
\hline $\begin{array}{l}\text { Ireland } \\
\text { United Kingdom }\end{array}$ & 1941 & Kurt Billig & Pre-stressed Reinforced Concrete \\
\hline Germany & 1942 & Emil Mörsch & Spannbetonträger \\
\hline Switzerland & 1946 & Max Ritter and Pierre Lardy & Vorgespannter Beton \\
\hline France & 1947 & V. Weinberg and W. Kravtzoff & Le Béton Précontaint \\
\hline United Kingdom & 1948 & Gustav Magnel & Prestressed Concrete \\
\hline United Kingdom & 1949 & William Paul Abeles & The Principles and Practice of Prestressed Concrete \\
\hline
\end{tabular}

\section{References}

1. Guyon, Yves, and Eugène Freyssinet. 1965. Hormigón Pretensado: Estudio Teorético y Experimental. Translated by Manuel Osset and Renato Bardin. Madrid, Spain: Dossat. Originally published as Béton Précontraint. Étude Théorique et Expérimentale (Paris: Editions Eryolles, 1951).

2. Bažant, Zdeněk P., Mija H. Hubler, and Qiang Yu. 2011. "Pervasiveness of Excessive Segmental Bridge Deflections: Wake-Up Call for Creep." Structural Journal 108 (6): 766-774.

3. Fernández Ordóñez, José A. 1978. Eugène Freyssinet. Barcelona, Spain: Xarait.

4. Dobell, Curzon. 1950. "Patents and Codes Relating to Prestressed Concrete." Journal of the American Concrete Institute 46 (5): 713-722.

5. Billig, Kurt. 1952. Prestressed Concrete. London, UK: Macmillan.

6. Ritter, Max, and Pierre Lardy. 1946. Vorgespannter Beton. Zurich, Switzerland: Leeman.

7. Leonhardt, Fritz. 1967. Hormigón Pretensado. Translated by Alberto Corral, Juan Batanero. Madrid: Instituto Eduardo Torroja de la Construcción y el Cemento. Originally published as Spannbeton für die Praxis, 2nd ed. (München: Wilhelm Ernst \& Sohn, 1962.

8. Griggs, Francis E. Jr., and A. J. DeLuzio. 1995. "Stephen H. Long and Squire Whipple: The First American Structural Engineers." Journal of Structural Engineering 121 (9): 1352-1361.

9. Gasparini, Dario, and David Simmons. 1997. "American Truss Bridge Connections in the 19th Century. I:
1829-1850." Journal of Performance of Constructed Facilities 11 (3): 119-129.

10. Long, Stephen H. Truss bridge. US Patent X5862, issued March 6, 1830.

11. Finsterwalder, Ulrich. Truss girder and method of producing the same. US Patent 2151267, filed June 10, 1937, and issued March 21, 1939.

12. Bailey, Michael R. 2003.Robert Stephenson: The Eminent Engineer. Farnham, UK: Ashgate.

13. Sutherland, James. 2009. "The Birth of Prestressing? Iron Bridges for Railways 1830 to 1850." International Journal for the History of Engineering and Technology 79 (1): 113-130.

14. Her Majesty's Stationery Office. 1849. Report of the Commissioners Appointed to Inquire into the Application of Iron to Railway Structures. London, UK: Her Majesty's Stationery Office.

15. Whipple, Squire. Bridge. US Patent 2064, issued April $24,1841$.

16. Griggs, Francis E. Jr. 2002. "Squire Whipple—Father of Iron Bridges." Journal of Bridge Engineering 7 (3): 146-155.

17. 1908. New York Times. http://newspaperarchive.com. June 18, p. 14.

18. Wermiel, Sara E. 2009. "California Concrete, 18761906: Jackson, Percy, and the Beginnings of Reinforced Concrete Construction in the United States." In Proceedings of the Third International Congress on Construction History. Cottbus, Germany: Brandenburg University of Technology.

19. Simonnet, Cyrille. 2005. Le Béton: Histoire d'un Ma- 
Table 3: Early posttensioning systems in Europe and the United States, 1950 to 1955

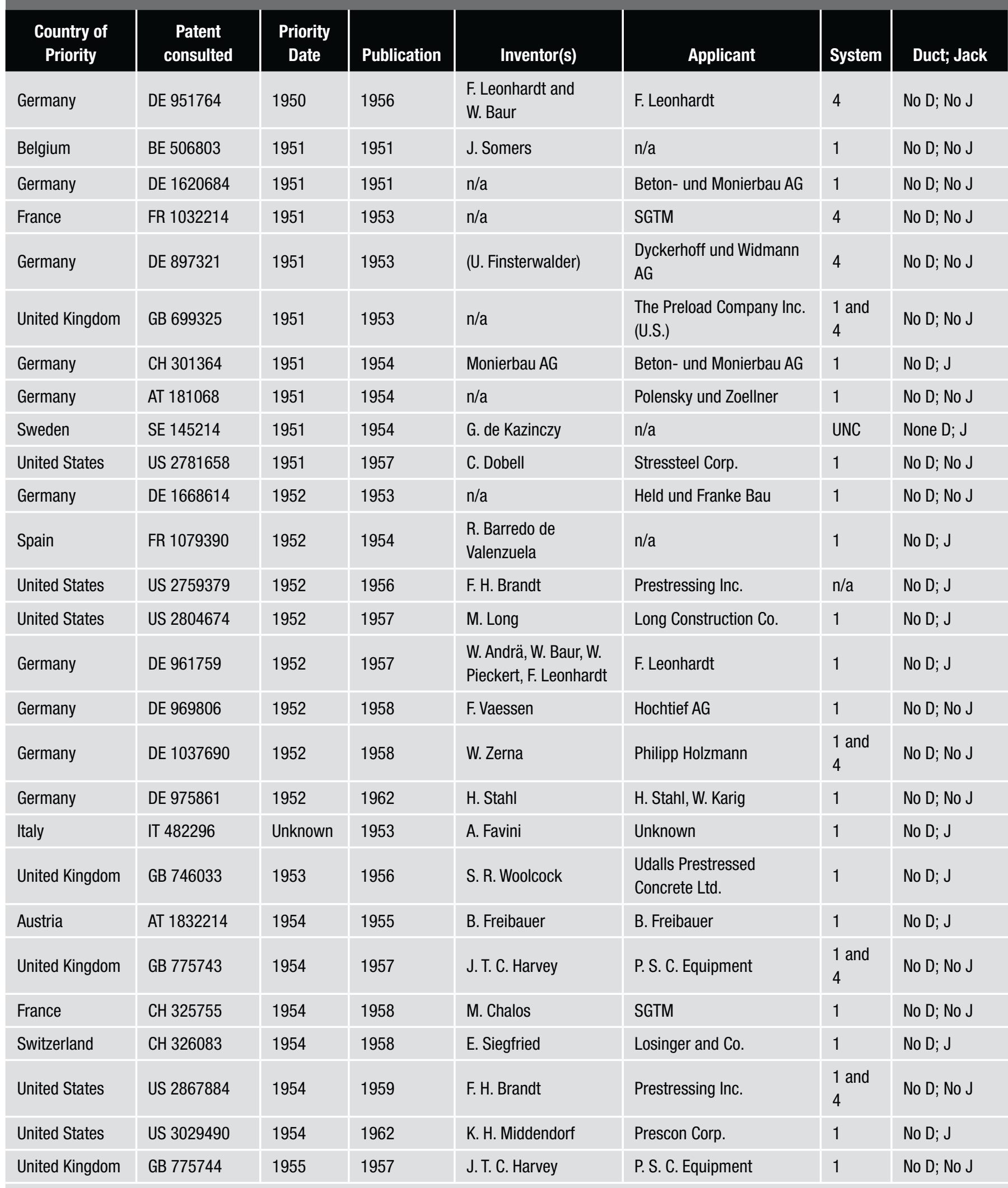

Note: (Actual inventor); 1 = anchorage system; 2 = precompressed steel nucleus; $3=$ overlapped loops; $4=$ bars and nuts; $\mathrm{D}=$ systems that include the description of a duct; $\mathrm{J}=$ systems that include the description of a jack; $n / a=$ not applicable; No $\mathrm{D}=$ systems that do not include the description of a duct; $\mathrm{No} \mathrm{J}=$ systems that do not include the description of a jack; None $\mathrm{D}=$ systems where a duct is not necessary; None $\mathrm{J}=$ systems where a jack is not necessary; SGTM = Société Générale de Travaux de Marseille; UNC = systems that cannot be classified into any of the four main families. 


\begin{tabular}{|l|l|l|l|}
\hline \multicolumn{1}{|c|}{ Publication country } & \multicolumn{1}{|c|}{$\begin{array}{c}\text { Publication } \\
\text { date }\end{array}$} & \multicolumn{1}{|c|}{ Author(s) } & \multicolumn{1}{c|}{ Title } \\
\hline France & 1950 & Jean Barets & Le Béton Précontraint: Théorie et Calculs \\
\hline France & 1951 & Yves Guyon & Béton Précontraint. Étude Théorique et Expérimentale \\
\hline United Kingdom and & 1952 & Kurt Billig & Prestressed Concrete \\
\hline United States & 1952 & August Komendant & Prestressed Concrete Structures \\
\hline United States & 1953 & Francis Walley & Prestressed Concrete, Design and Construction \\
\hline United Kingdom & 1954 & Fritz Leonhardt & Spannbeton für die Praxis \\
\hline Germany & 1954 & Hans Möll & $\begin{array}{l}\text { Spannbeton: Entwicklung, Konstructionen, Herstellungsverfahren und } \\
\text { Anwendungsbeite }\end{array}$ \\
\hline Germany & 1955 & Victor Weinberg & Manuel du Béton Précontraint \\
\hline France & 1955 & Tung-Yen Lin & Design of Prestressed Concrete Structures \\
\hline United States & 1955 & Gaspar Kani & Spannbeton in Entwurf und Ausführung \\
\hline Germany & & & \\
\hline
\end{tabular}

Table 5: Early congresses and conferences on prestressed concrete in Europe and the United States, 1950 to 1957

\begin{tabular}{|l|l|l|l|}
\hline \multicolumn{1}{|c|}{ Year } & \multicolumn{1}{|c|}{ Country } & \multicolumn{1}{|c|}{ Location } & \multicolumn{1}{|c|}{ Name of congress or conference } \\
\hline 1950 & France & Paris & Premier Congres International du Béton Précontraint \\
\hline 1951 & United States & $\begin{array}{l}\text { Massachusetts Institute of } \\
\text { Technology }\end{array}$ & First United States Conference on Prestressed Concrete \\
\hline 1953 & United Kingdom & Cambridge University & First Congress of the Fédération Internationale de la Précontrainte \\
\hline 1955 & Netherlands & Amsterdam & Second Congress of the Fédération Internationale de la Précontrainte \\
\hline 1957 & United States & University of California, Berkeley & World Conference on Prestressed Concrete \\
\hline
\end{tabular}

tériau: Économie, Technique, Architecture. Marseille, France: Parenthèses.

20. Jackson, Peter H. Construction of metallic side pavements. US Patent 21834, filed February 2, 1858, and issued October 19, 1858.

21. Nawy, Edward G. 2009. Prestressed Concrete: A Fundamental Approach. Upper Saddle River, NJ: Pearson.

22. Jackson, Peter H. Improvement in girders. US Patent 126396, issued May 7, 1872.

23. Jackson, Peter H. Arched girder. US Patent 265321, filed April 11, 1882, and issued October 3, 1882.

24. Jackson, Peter H. Building or bridge construction. US Patent 366839, filed January 7, 1886, and issued July 19, 1887.

25. Jackson, Peter H. Construction of artificial-stone or concrete pavements. US Patent 375999, filed Octo- ber 27, 1886, and issued January 3, 1888.

26. Billington, David P. 2004. "Historical Perspective on Prestressed Concrete.” PCI Journal 49 (1):14-30.

27. Lee, Thomas A. Artificial fire-proof joist for floors or roofs. US Patent 461028, filed December 20, 1890, and issued October 13, 1891.

28. Lee, Thomas A. Tension-rod. US Patent 513794, filed April 30, 1892, and issued January 30, 1894.

29. Vander Heyden, Bernard A. Cementitious plank and method of constructing it. US Patent 2696729, filed June 19, 1944, and issued December 14, 1954.

30. Dolhon, Anthony M. 2008. "Performance Evaluation of Dox Plank." In AEI 2008: Building Integration Solutions. Denver, CO: ASCE Publications.

31. Doehring, C. F. Einrichtung zur Herstellung von mit Draht durchzogenen, zu dem unter No. 49024 paten- 
tirten Abschluss für Balkenlangen zu verwendenden Latten. Prussian Patent 53548, filed October 23, 1888, and issued October 2, 1890.

32. Zilch, K., and H. Weiher. 2008. "120 Jahre Spannbetonbau-von Doehring und Jackson bis heute." Beton- und Stahlbetonbau 103 (6): 422-430.

33. Doehring, C. F. Feuersichrer und wasserdichter Abschluss für Stockwerksbalkenlagen. Prussian Patent 49024, filed June 3, 1888, and issued October 15, 1889.

34. Iori, Tullia. 2003. "Prestressed Concrete: First Developments in Italy." In Proceedings of the First International Congress on Construction History, 1167-1176. Madrid, Spain: Reverte.

35. Chaudy, François. 1894. "Sur le Calcul des Plaques Élastiques Minces et le Rôle de Tirants Dans les Poutres en Ciment Armées." In Mémoires et Compte Rendus des Travaux de la Société de Ingénieurs Civils de France, 2ème Semestre, 545-550. Paris, France: Société des Ingénieurs Civils de France.

36. Mandl, Julius. 1896. "Zur Theorie der CementeisenConstructionen." Zeitschrift des Österreichischen Ingenieur- und Architekten-Vereines XLVIII (45): 593-596.

37. Mandl, Julius. 1896. "Zur Theorie der CementeisenConstructionen." Zeitschrift des Österreichischen Ingenieur- und Architekten-Vereines XLVIII (45): 593-596 and XLVIII (46): 605-609.

38. Lund, Jens Gabriel. Straight vault. US Patent 1028578, filed February 10, 1908, and issued June 4, 1912.

39. Wilson, Walter. Improvements relating to reinforced concrete blocks, slabs and beams and the like. UK Patent 103681, filed January 31, 1916, and issued January 31, 1917.

40. Bolton, Frederick. Improvements in the manufacture of reinforced concrete structures. UK Patent 123100, filed March 28, 1918, and issued April 28, 1919.

41. Mezzetti, Ernesto. Innovazione nei sistemi di armatura del cemento. Italian Patent 166844, filed May 20, 1918, and issued September 5, 1918.

42. Wettstein, Karl. Verfahren zur Herstellung von Dielen, Schwellen, Brettern, Latten, Reigeln u. dgl. Aus Zement. Austrian Patent 95934, filed November 30, 1921, and issued September 15, 1923.
43. Hoyer, Ewald. Procedé pour faire du béton armé. French Patent 837141, filed November 3, 1938 (with German priority of April 28, 1937), and issued February $2,1939$.

44. Dischinger, Franz. Système porteur, en particulier pour ponts à poutres. French Patent 798928 , filed December 7, 1935, and issued March 14, 1936.

45. Finsterwalder, Ulrich. Ferro-concrete beam.US Patent 2155121, filed June10, 1937, and issued April 18, 1939.

46. Xercavins, Pierre, David Demarthe, and Ken Shushkewich. 2010. "Eugène Freyssinet-His Incredible Journey to Invent and Revolutionize Prestressed Concrete Construction." In Proceedings of the Third fib International Congress. Washington DC: Curran Associates Inc.

47. Considère, Armand. 1899. "Variations de Volume de Mortiers de Ciment de Portland, Résultant de la Prise et l'etat Hygrometrique." Comptes Rendus des Séances de l'Académie des Sciences 129 (July-December): 467-472.

48. Koenen, Mathias. 1907. "Wie Kann die Anwendung des Eisenbetons in der Eisenbahnverwaltung Wesentlich Gefördert Werden?" Zentralblatt der Bauverwaltung XXVII (79): 520-522.

49. Koenen, Mathias. Verfahren zur Erzeugung einer Anfangsdruckspannung in der Zugzone von Eisenbetonbalken oder-platten. German Patent 249007, filed January 18, 1912, and issued July 9, 1912.

50. Steiner, Charles R. Reinforced concrete construction. US Patent 903909, filed February 10, 1908, and issued November 17, 1908.

51. Woolson, Ira H. 1905. "Some Remarkable Tests Indicating 'Flow' of Concrete under Pressure." Engineering News 18 (54):459.

52. Hatt, W. K. 1907. "A Note on the Effect of Time Element in Loading Reinforced Concrete Beams." Engineering News 58(17): 438-439.

53. McMillan, Franklin R. 1915. Shrinkage and Time Effects in Reinforced Concrete. Minneapolis, MN: University of Minnesota.

54. Smith, E. B. 1916. "Concrete Flows under Sustained Load.” Engineering Record 73(10): 329-330.

55. Espion, Bernard. 2012. "L'Invention du Béton Précontraint par Eugène Freyssinet et Premières Applications de Ses Brevets." http://difusion.ulb.ac.be/vufind/re- 
cord/ulb-dipot:oai:dipot.ulb.ec.be:2013/115846/holdings. Paper presented at Connaissez-vous les Bétons Armés et Précontraints? Université Libre de Bruxelles, Moulins de Beez, Belguim.

56. Grote, Jupp, and Bernard Marrey. 2000. Freyssinet, la Précontrainte et l'Europe. Der Spannbeton und Europa. Prestressing and Europe. 1930-1945. Paris, France: Éditions du Linteau.

57. Lévy, Maurice. 1907. "Circulaire du 20 Octobre 1906, Concernant les Instructions Relatives à l'Emploi du Béton Armé." La Houille Blanche (7): 148-152.

58. Balcom, Thomas W. 1984. "A Tale of Two Towers. Washburn Park and Its Water Supply." Minnesota History 49 (Spring): 19-28.

59. Faber, Oscar. 1927. "Plastic Yield, Shrinkage and Other Problems of Concrete and Their Effect on Design." In Proceedings of the Institution of Civil Engineers, 27-73. London, UK: Institution of Civil Engineers.

60. Freyssinet, Eugène. 1930. "Études sur les Déformations Lentes des Ciments ou Retraits." In Premier Congrès International du Béton et du Béton Armé, 520-532. Liège, Belgium: La Technique des Travaux

61. Freyssinet, Eugène. 1966. "Relations Entre les Deformations et la Constitution des Ciments et des Matériaux de Structure Colloïdale (Résultats de Recherché Faites par Eugène Freyssinet entre 1926 et 1929)." Travaux 376 (Numéro spécial - Un demi-sciècle de technique française de la précontrainte - Tome II): 921-936.

62. Glanville, W. H. 1930. Studies in Reinforced Concrete III: The Creep or Flow of Concrete under Load. Building research technical paper n. 12. London: UK: Her Majesty's Stationery Office.

63. Dischinger, Franz. 1937. "Untersuchungen über die Knicksicherheit, die Elastische Verformung und das Kriechen des Betons bei Bogenbrücken.” Der Bauingenieur 18 (33/34): 487-520.

64. Dischinger, Franz. 1937. "Untersuchungen über die Knicksicherheit, die Elastische Verformung und das Kriechen des Betons bei Bogenbrücken.” Der Bauingenieur 18 (35/36): 539-552.

65. Dischinger, Franz. 1937. "Untersuchungen über die Knicksicherheit, die Elastische Verformung und das Kriechen des Betons bei Bogenbrücken." Der Bauingenieur 18 (39/40): 595-621.

66. Dischinger, Franz. 1939. "Elastische und Plastische
Verformungen bei Eisenbetontragwerke." Der Bauingenieur 20 (5/6): 53-63.

67. Dischinger, Franz. 1939. "Elastische und Plastische Verformungen bei Eisenbetontragwerke." Der Bauingenieur 20 (21/22): 286-294.

68. Dischinger, Franz. 1939. "Elastische und Plastische Verformungen bei Eisenbetontragwerke." Der Bauingenieur 20 (31/32): 426-437.

69. Dischinger, Franz. 1939. "Elastische und Plastische Verformungen bei Eisenbetontragwerke." Der Bauingenieur 20 (47/48): 563-572.

70. Melan, Joseph. Vault for ceilings, bridges, etc. US Patent 505054, filed May 17, 1893, and issued September 12, 1893.

71. Hewett, William S. Reinforced concrete structure. US Patent 1413404, filed March 5, 1921, and issued April 18, 1922.

72. Dill, Richard E. Manufacture of reinforced concrete. US Patent 1684663, filed February 7, 1925, and issued September 18, 1928.

73. Färber, Richard. Verfahren zur Herstellung von Verbundträgern aus Eisenbeton. German Patent 557331, filed May 29, 1927, and issued August 22, 1932.

74. Hewett, William S. Method and means for tying concrete. US Patent 1818254, filed September 10, 1927, and issued August 11, 1931.

75. Hewett, William S. Building structure reinforcement. US Patent 2091444, filed December 9, 1935, and issued August 31, 1937.

76. Freyssinet, Eugène. 1928. "L'Amélioration des Constructions en Béton Armé par L'Introduction de Déformations Élastiques Systématiques." Génie Civil 11 (93): 254-257.

77. Freyssinet, Eugène, and Jean Seailles. Procédé de fabrication de pièces en béton armé. French Patent 680547, filed October 2, 1928, and issued May 1, 1930.

78. Freyssinet, Eugène. 1933. "Idées et Voies Nouvelles." Science et Industrie 1 (1): 3-17.

79. Freyssinet, Eugène. 1936. Une Revolution dans la Technique du Béton. Paris, France: Eyrolles.

80. Freyssinet, Eugène. Système d'ancrage de câbles sous tension destines à la réalisation de constructions en béton précontraint. French Patent 926505, filed Au- 
gust 26, 1939, and issued October 3, 1947.

81. Gueritte, Alfred T. Improvements in or relating to the Construction of Prestressed Concrete. UK Patent 541437, filed August 13, 1940, and issued November 26, 1941.

82. Kirkwood, Archibald, and The Prestressed Concrete Company. Improvements in or relating to the stretching and anchorage of cables or bundles of hard steel wires for prestressed reinforced concrete. UK Patent 541160, filed August 27, 1940, and issued November $14,1941$.

83. Freyssinet, Eugène. Improvements in processes and devices for anchoring wires reinforcing pre-stressed concrete structures. UK Patent 591218, filed February 21, 1941, and issued August 12, 1947.

84. Freyssinet, Eugène. Dispositif de mise en tension et d'ancrage de cables convenant en particulier à la réalisation de constructions en béton précontraint. French Patent 870070, filed October 28, 1940, and issued 2, March, 1942.

85. Freyssinet, Eugène. Dispositif de vérin et ses applications. French Patent 859903, filed June 3, 1939, and issued January 2, 1941.

86. Emperger, Fritz. Reinforced concrete. US Patent 2255022, filed February 3, 1940 (with German priority of January 23, 1939), and issued September 2, 1941.

87. Magnel, Gustav. 1945. "Le Fluage des Aciers et son Importance en Béton Précontraint." Science et Technique 1945 (2): 4-8.

88. Magnel, Gustav. 1944. "Le Flambage en Béton Précontraint." Science et Technique 1944 (10): 1-4.

89. Schorer, Herman. Mode de construction en béton, dans lequel les pieces soumises en fonctionnement normal à des efforts de traction et de cisaillement, reçoivent une tension initiale, et dispositif pour cette mise en tension. French Patent 870671, filed February 20, 1941, and issued March 20, 1942].

90. Lesage, Gilbert. Procédé de mise en tension d'armatures pour béton précontraint, et dispositif pour se mise en œuvre. French Patent 954204, filed October 13, 1947, and issued December 21, 1949. 


\section{About the authors}

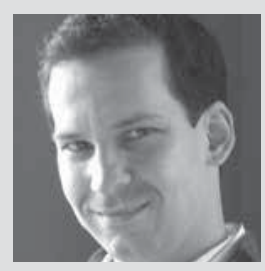

Marc Sanabra-Loewe is a lecturer and a licensed architect specializing in structural analysis. He has been involved in the design of more than $7,500,000 \mathrm{ft}^{2}$ of built structures. He teaches structures construction to undergraduate students at the Universitat Politècnica de Catalunya (Barcelona Tech) in Spain and is coordinator of the Post-Tensioning Structures in Building Construction Task Group of the Asociación de Consultores de Estructuras, the main Spanish structural consultants association. He is working on a $\mathrm{PhD}$ on posttensioning precast concrete elements for building construction and is also researching slab optimization through refined predimensioning methods.

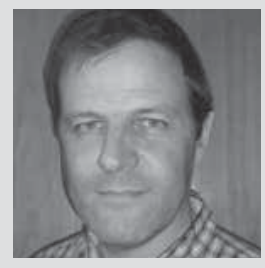

Joaquin Capellà-Llovera is a lecturer and has been one of the leading members of the directorate of the Building Engineering Faculty of the UPC (EPSEB) for six years. He received his doctorate in 2012 from the Universidad

Camilo José Cela in Madrid, Spain, for his work on the commercialization of innovative concretes, including self-consolidating concrete, high-performance concrete, and fiber-reinforced concrete. He has a bachelor's degree in construction engineering with an emphasis on architectural engineering and industrial organization. He specializes in building construction and building retrofit.

\section{Abstract}

Unlike that of reinforced concrete, the history of prestressed concrete has been insufficiently studied. Little progress has been made since the first classical texts appeared in England, the United States, and Germany soon after the Second World War, and after the publicaiton of the classical biography of Fressinet following Spain's return to democracy. Some evidence of this gap is that some well reputed textbooks on prestressed concrete, as well as recent and updated papers, still repeat the old erroneous chronologies. However, in recent decades some researchers have been making interesting and noteworthy advances in the history of prestressed concrete. Some of these advances are discussed here, along with new data from the study of early patents on prestressed structures, and these resources are looked at from a new historical perspective: the four ages of prestressed concrete structures. Beyond application to concrete structures, this "four ages" perspective can also be useful for studying the history of prestressed structures made of other materials.

\section{Keywords}

Eugène Freyssinet, history, Peter H. Jackson, prestressing.

\section{Review policy}

This paper was reviewed in accordance with the Precast/ Prestressed Concrete Institute's peer-review process.

\section{Reader comments}

Please address and reader comments to journal@pci .org or Precast/Prestressed Concrete Institute, c/o PCI Journal, 200 W. Adams St., Suite 2100, Chicago, IL 60606. D 